\title{
Direito, Estado e Telecomunicações: o ano em que o espectro novamente encolheu (Apresentação)
}

Law, State and Telecommunications: the year the spectrum shrank, again (Presentation)

\begin{abstract}
Resumo
O presente estudo figura como introdução à Revista de Direito, Estado $e$ Telecomunicações do Grupo de Estudos em Direito das Telecomunicações da Universidade de Brasília, abordando sinteticamente a estrutura, conteúdo e política editorial da revista. Em acréscimo, o texto analisa os principais acontecimentos do setor no Brasil, bem como normas e julgados relativos ao ano de 2009, para registro das principais discussões político-jurídicas do setor de telecomunicações brasileiro referentes ao ano anterior ao da publicação.
\end{abstract}

\section{Abstract}

This text introduces the Law, State, and Telecommunications Review, addressing, by way of an overview, its structure, contents and editorial policy. Besides that, this introduction defines the underpinnings of the journal's regulatory approach. Statutes, administrative regulation and judicial decisions of 2009 pertaining to telecommunications are referred to in detail. It also addresses the main political and juridical discussions about the Brazilian telecommunications sector that took place the year before the publication of the journal's volume.

\section{Apresentação}

Em consonância com o propósito inaugural da Revista de Direito, Estado e Telecomunicações, apresenta-se o segundo volume da publicação segundo o formato que se segue, mantendo-se a perspectiva de consolidação da revista como um instrumento de pesquisa jurídica setorial.

Para tanto, a presente apresentação vai além da identificação das temáticas constantes da publicação e dá sequência ao registro histórico do arcabouço normativo setorial e do correspondente contexto socioeconômico e político das telecomunicações no Brasil. O artigo introdutório também registra as principais discussões jurídico-regulatórias que marcaram o ano de 2009.

O leitor se depara, em seguida, com o segundo tópico da revista, que corresponde a dois estudos traduzidos para a língua portuguesa de Clara-Luz 
Álvarez e de Lucas Sierra. O primeiro artigo da seção de estudos estrangeiros é intitulado "TV Móvel: onde estamos e para onde vamos" e se configura em texto de caráter predominantemente informativo, preocupando-se com a distinção conceitual tão importante para fins de aplicação do ordenamento jurídico, entre IPTV, TV móvel e TV pela internet. Mediante estudo de caso do México, o artigo descreve os desafios de regulamentação da rede, espectro e equipamentos pertinentes à TV móvel. É importante notar a preocupação da autora em demonstrar que a presença de novas tecnologias, como as pertinentes à TV móvel, abre a possibilidade de opção por diversos caminhos regulatórios. Uma determinada tecnologia pode ser classificada sob enfoques normativos distintos e, a depender da classificação que se lhe aplica, dita inovação tecnológica pode ser entendida tão somente como uma característica geral de serviços específicos, de um lado, ou como o próprio critério classificatório adotado para distinção regulatória dos serviços de telecomunicações. Por isso, é uma opção regulatória dependente da correspondente classificação normativa entender-se as categorias de TV móvel radiodifusora e de TV móvel transmitida pelas redes celulares como serviços distintos com uma característica comum de transmissão de sinais televisivos, ou como integrantes de um novo serviço chamado TV Móvel. O texto, portanto, reforça a importância da fixação de parâmetros normativos que acompanhem a velocidade de inovação tecnológica do setor de telecomunicações, mas reconhece que a convergência experimentada na transmissão televisiva e o rol de opções regulatórias geradas pela possibilidade de TV móvel dificultarão a imposição de limites regulatórios para autorização de uso de espectro de radiofrequência, com a previsível escalada de ações judiciais a esse respeito. O segundo artigo é intitulado "Reforma legislativa da televisão no Chile ante o futuro digital: um passo a frente, outro atrás". Nele, Lucas Sierra analisa a iniciativa do governo chileno de reforma da legislação de radiodifusão em 2009 mediante avaliação dos impactos positivos ou negativos na tensão entre intervenção estatal e as correspondentes liberdades atingidas pelas mudanças normativas propostas a título de transição digital. Em meio à análise dos prós e contras da reforma chilena da TV aberta, o autor afirma, en passant, que o ordenamento jurídico chileno não reconhece o direito das concessionárias de radiodifusão ao uso de uma faixa específica do espectro ou ao uso de Revista de Direito, Estado e Telecomunicações, v. 2, n. 1, p. 1-44 (2010) DOI: https://doi.org/10.26512/lstr.v2i1.21682 
determinada quantidade do espectro, mas tão somente o espectro necessário à transmissão do sinal televisivo. Enfim, a partir da exaltação da proposta de criação da categoria jurídica de concessão de serviços intermediários na radiodifusão, por um lado, e de críticas ao avanço do radiodifusor televisivo estatal chileno (TVN) para além da função de subsidiariedade da TV aberta estatal frente à privada, o autor conclui pela caracterização da proposta como um avanço em determinados pontos, mas um retrocesso em outros, em especial no tocante às garantias de diversidade e liberdades de expressão e econômica preexistentes à reforma. Para além das considerações valiosas sobre o direito chileno, o artigo oferece um importante registro histórico das discussões inauguradas no âmbito legislativo para transição digital da TV aberta no Chile.

O terceiro tópico da revista é dedicado à apresentação de estudos selecionados que abordem questões jurídicas relevantes do setor de telecomunicações brasileiro. No presente número, o artigo de Laura Lira aborda o regime jurídico de controle de conteúdo na radiodifusão, com especial atenção às formas de controle preventivo administrativo, judicial e legislativo previstas no arcabouço normativo brasileiro incidentes sobre as mídias de comunicação social de massa, bem como no que se refere à possibilidade jurídica de mecanismos de proteção de programação nacional propostos no Projeto de Lei 29/2007, em tramitação no Congresso Nacional. O segundo estudo publicado neste número, de André Gomes, situa o conceito de empreendedorismo na rede de direitos e garantias constitucionais objetivadas enquanto princípios jurídicos no Brasil, correlacionando-o aos princípios da liberdade de iniciativa e da livre concorrência e antecipando parte das discussões que precipitaram o lançamento da consulta pública para o operador virtual de rede móvel no Brasil (MVNO). A partir da teorização do empreendedorismo como categoria principiológica jurídica, o artigo o aplica a um caso de requerimento administrativo de outorga de autorização para prestação de Serviço Móvel Especializado (SME) em faixa de radiofrequência destinada ao Serviço Móvel Pessoal (SMP), mediante exploração industrial da integralidade da rede de acesso rádio. No estudo, conclui-se por uma diferente solução jurídica ao caso Actium, tendo-se em vista a garantia de um princípio empreendedor no setor de telecomunicações. 
Para a quarta seção da revista, foi reservado espaço à transcrição de palestra proferida no ano de 2009. Sob o título "Políticas de Inclusão Social para o Acesso em Banda Larga: casos do sul da Ásia", Helani Galpaya expõe aspectos relevantes das políticas de países da região - em especial do Sri Lanka - e chama a atenção da audiência ao afirmar enfaticamente que a principal medida garantidora do direito de acesso a serviços de telecomunicações a preços justos não depende de medidas governamentais que preservem a isonomia ou a lisura de procedimentos licitatórios, mas essencialmente da tomada de decisão política voltada a autorizar tantos novos entrantes quantos forem possíveis nos diversos mercados de telecomunicações. Segundo a pesquisadora, mais valem inúmeras licenças em procedimentos corruptos e viciados, que poucas bem acompanhadas. Trata-se, certamente, de uma questão delicada, pois lida, por um lado, com os limites juridicamente justificáveis de aplicação de garantias de lisura e isonomia nos procedimentos licitatórios para uso de radiofrequência e para prestação de serviços de telecomunicações, e por outro lado, com o efeito anti-isonômico gerado pela aplicação incondicional e imponderada de tais garantias, que não raramente leva ao bloqueio ou postergação de medidas administrativas voltadas ao ingresso de novos competidores no setor e, em última instância, ao direcionamento da atividade de controle estatal para o benefício de empresas dominantes. As dificuldades experimentadas, no Brasil, para uso dos recursos do Fundo de Universalização refletem a importância de se passar a limpo a questão dos limites das garantias de lisura e isonomia nas licitações, que, se aplicados incondicionalmente, se convertem eles mesmos em mecanismos anti-isonômicos de preservação de privilégios. Um exemplo de como a atividade de controle pode servir aos fins de preservação dos interesses econômicos das empresas já instaladas no setor encontra-se na tendência sempre crescente de se exigir dos reguladores a elevação dos preços públicos das outorgas de radiofrequência e de serviços, chamando-nos a atenção para a afirmação de Chowdary ${ }^{1}$ de que "a ganância [do governo] deve ceder à necessidade do povo", e de que exigências de exaustivos estudos prévios para novas licenças de radiofrequências "são piores que a doença que pretendem atacar [pois]

${ }^{1}$ CHOWDARY, T. H. Telecoms to the Villages. p. 1997. In: Economic and Political Weekly, vol. 35, n. 24, Junho 10-16, 2000, p. 1995-1997.

Revista de Direito, Estado e Telecomunicações, v. 2, n. 1, p. 1-44 (2010)

DOI: https://doi.org/10.26512/lstr.v2i1.21682 
infligem uma paralisia financeira na infância de [novas] empresas privadas de telecomunicações" ou de novos empreendimentos. A questão é mais atual do que se pode pensar, pois em posicionamento da Controladoria-Geral da União deste ano de 2010, reconhece-se, em auditoria regular de gestão da ANATEL, a ausência de diligência por parte da agência na prorrogação de licenças de operação do MMDS efetivada em fevereiro de 2009 em razão, principalmente, de implicações na performance da receita pública, com flagrante dano ao erário. A confusão do interesse público com o abastecimento do erário demonstra como a regulação setorial ainda tem um longo caminho a seguir para ponderação de princípios de proteção do consumidor, de processo administrativo e de controle no Brasil.

Em sequência, o livro "Transforming Global Information and Communication Markets: The Political Economy of Innovation", de autoria de Peter Cowhey e Jonathan Aronson, publicado em 2009, encontra-se resenhado por Renata Quelho no trabalho intitulado "O caminho da mudança: fatores-chave para a nova etapa nos Mercados Globais de Informação e Comunicação", afirmando a importância da política pública governamental em sua dimensão nacional e internacional para conformação do mercado de tecnologias da informação e comunicação (TIC) hoje caracterizado pela modularidade, bem como da importância de que os formuladores da política pública tenham ciência desse papel fundamental da política pública setorial, que, no caso de mercados de serviço sem fio, lida com a inerente tensão entre a concepção do espectro como bem público e os direitos de propriedade dos atores setoriais e, nos mercados em geral de TIC, promovem à harmonização de padrões globais definidores das possibilidades de investimento e desenvolvimento. O que instiga o leitor no livro resenhado é o reconhecimento derivado de casos principalmente na arena das tecnologias sem fio de que a conformação do mercado depende fortemente de um conjunto de forças políticas com dimensão internacional, ao mesmo tempo em que se destaca a atuação do mercado como, ao menos em parte, um produto gerado pelas constrições normativas do setor expressas em regras de governança internas capazes de influenciar as regras de governança de um mercado global.

A sexta seção da revista dedica-se ao registro do estágio em que se encontram temáticas atuais do setor de telecomunicações brasileiro traduzidas nos chamados informes setoriais. Os informes são registros do 
andamento de determinados temas relevantes ao setor de telecomunicações. Neste número da revista, encontra-se o informe relativo ao chamado Canal de Mensagem de Trânsito, também referido pela sigla TMC (Traffic Message Channel), de autoria de Egon Guterres, em que se analisa o estado da técnica de aplicação de tal solução tecnológica em diversos países, bem como os benefícios trazidos por sua promoção para, com isso, concluir pela importância do Estado se envolver na cadeia de informação do TMC para garantia da qualidade dos dados das tabelas de códigos de localizações e eventos, bem como para viabilização de implementação de um modelo híbrido de informações de trânsito, que se mescle a um produto comercial de mensagens livres e abertas de interesse público. O segundo informe setorial de autoria de Miriam Wimmer contextualiza os diversos projetos de lei em tramitação no Congresso Nacional sobre o tema da comunicação de massa por assinatura, tão em voga nos primeiro meses de 2010 .

Segue-se, na sétima seção da revista, o registro dos trabalhos acadêmicos de doutorado e de mestrado apresentados nos anos de 2007 e 2009, na Universidade de Brasília, na pós-graduação em direito e em áreas afins reputados de interesse para o estudo jurídico do setor de telecomunicações sobre os temas da separação de poderes em direito comparado, da adequação de mecanismos regulatórios setoriais a princípios constitucionais do mercado e da universalização de serviços públicos. Ao final da sétima seção, consta uma seleção de pesquisas acadêmicas de interesse para o direito das telecomunicações finalizadas no período de 2007 a 2009 em nível de pós-graduação e de graduação na Universidade de Brasília.

Finalmente, a última seção da revista é dedicada à reunião das normas e julgados do setor de telecomunicações do ano de 2009 organizadas por temas e referenciadas a tabelas informativas. No início dessa seção, consta a lista de abreviaturas e siglas do setor de telecomunicações mantida pelo GETEL/UnB, bem como, ao final, foi inserido um exaustivo índice alfabético e remissivo das normas e julgados do setor no ano de 2009. Cada tema presente em dita seção contém referências a julgados, a normas de todos os níveis e a atos administrativos correlatos identificados por símbolos criados pelo Núcleo de Multimídia e Internet da UnB. 


\section{Filosofia da publicação}

A perspectiva orientadora da publicação consta de seu título como revista científica que reconhece a intercomunicação entre os papéis do Direito e do Estado no setor de telecomunicações. Mais ainda, a proposta de estudos jurídicos dirigida à interseção das rubricas estatal e telecomunicacional esboça uma concepção de direito regulatório em que o desenvolvimento setorial é visto como um empreendimento resultado da confluência de atores públicos e privados em meio a parâmetros jurídicos superiores responsáveis por sua classificação como um projeto público. Tem-se presente o princípio constitucional norteador da regulação setorial como um espaço de estudo do direito de liberdade política, que, dentre outras dimensões, incorpora ao verbo 'regular' a ação a ele correspondente de reconhecimento do dever do cidadão a aprender a se governar. O estudo do direito das telecomunicações tem por componente diretivo o significado do direito à autodeterminação e da virtude política.

Em outras palavras, a publicação não adota vieses predefinidos e, portanto, não se rende ao enfoque totalitário de esgotamento do sentido regulatório em mitos, sejam eles mitos assentados no fundamentalismo ou magia de mercado, sejam mitos assentados na suficiência quase exclusiva do Estado. A presente publicação, como espaço de discussão e encontro de pontos de vista, encontra-se aberta a todas as correntes. Se não se pode defender a suficiência de um mercado destacado de fatores institucionais jurídicos, também não se pode defender o pressuposto da suficiência do planejamento macro e microeconômico, que restringe as decisões privadas do setor a partir de uma administração burocrática gerencial centralizada incapaz de se adaptar às demandas de uma sociedade da informação. ${ }^{2}$ Em nenhuma destas hipóteses, o princípio constitucionalista participativo encontra-se respeitado. Ele somente se apresenta em sua plenitude quando se reconhece a regulação como um espaço institucional regulador de exercício da liberdade de participação política por todos os atores setoriais habilitados a se responsabilizarem pelo presente $\mathrm{e}$ futuro das telecomunicações.

${ }^{2}$ KISELYOVA, Emma; CASTELLS, Manuel. The collapse of Soviet Communism: a view from the information society. Berkeley: University of California, 1995. 
A presente publicação apresenta-se, portanto, como espaço público de discussão e confluência de todos os pontos de vista seriamente fundamentados e capazes de elevar o estado da arte da discussão jurídicoregulatória de telecomunicações.

\section{O setor de telecomunicações no ano de 2009}

Embora não se possa resumir sob o manto de uma única categoria o conjunto variado de temas relevantes que caracterizaram o setor de telecomunicações brasileiro em 2009, não é despropositado identificá-lo por algo que mais chamou a atenção e que se refere à mudança de perspectiva sobre a gestão do espectro. Ao se fazer a retrospectiva do ano de 2009, há um tópico que o diferencia dos demais e que se refere à forma como a destinação de espectro de radiofrequência passou a ser discutida não mais sob o enfoque de qual faixa de espectro será utilizada para um determinado serviço. A postura especulativa que permeou a destinação de espectro para a terceira geração de serviços móveis anos antes se apresentou, em 2009, com um ingrediente bem distinto: o da disputa entre serviços por ampliação ou manutenção de destinação de faixas de radiofrequência.

A continuidade da polêmica sobre a destinação da faixa de $2,5 \mathrm{GHz}$ é o exemplo contundente de como a definição pela forma de utilização do bem público do espectro de radiofrequências adquiriu um matiz diferencial que a propaganda de avanços tecnológicos manteve de certa forma obscurecido nos últimos anos, mas que a disputa por subfaixas de frequência novamente fez aflorar: a escassez do espectro. De um lado, representantes das associações de WIMAX (WIMAX Forum), de operadoras do serviço de MMDS no Brasil (Telefônica, Neotec, ABTA) e de provedores de internet e de comunicação de dados (Abramulti), enfatizando a importância de se utilizar a faixa de $2,5 \mathrm{GHz}$ segundo uma alocação mais flexível que levasse em conta a demanda real e corrente pelo espectro. Isto, ao invés de se preservar a faixa para o uso futuro do LTE, até então garantida pela indefinição regulatória e pela adoção da prática de não homologação, pela ANATEL, dos equipamentos correspondentes das operadoras de MMDS, sob a alegação de que a prestação de serviços de banda larga por tais empresas exigiria uma nova autorização de Serviço de Comunicação Multimídia (SCM). De outro lado, associações interessadas (GSM 
Association) e operadoras/associação de operadoras de SMP (Oi, Acel) ${ }^{3}$, defendendo que a adoção pelo Brasil do modelo sueco de destinação de 50 $\mathrm{MHz}$ no centro da faixa de 2,5 GHz para tecnologias TDD (WIMAX) e o restante para tecnologias FDD, como o LTE, seria essencial para se evitar o estrangulamento dos serviços de banda larga móvel do país a partir de 2011. ${ }^{4}$ Em meio ao crescente interesse parlamentar sobre o tema, em 30 de julho de 2009, o conselho diretor da ANATEL decidiu, tendo por base parecer da área técnica que propunha a retirada de $80 \mathrm{MHz}$ de um total de $190 \mathrm{MHz}$ destinados ao MMDS, pelo lançamento de consulta pública com indicação de progressiva restrição do uso da faixa de $2,5 \mathrm{GHz}$ pelas empresas prestadoras de MMDS, projetando-se para 2015 que elas se restringissem a $50 \mathrm{MHz}$, destinando-se $140 \mathrm{MHz}$ para o Serviço Móvel Pessoal (SMP). O encaminhamento para consulta pública, entretanto, não se deu sem atropelos, pois o Judiciário foi chamado a garantir a publicidade das razões de decidir do conselho diretor, quando a Neotec, em setembro de 2009, obteve liminar na justiça federal de Brasília, concedendo extensão do prazo para sua manifestação na consulta pública número 31 contado da divulgação administrativa do inteiro teor dos documentos utilizados pela agência para formulação da proposta de regulamentação da faixa de 2,5 GHz. Em grande medida, a tensão política sobre a destinação da faixa de 2,5 $\mathrm{GHz}$ fez uso da concepção jurídica sobre o método regulatório setorial adotado no país pautado na divisão por serviços - MMDS, SMP - vinculados normativamente a determinadas utilidades - TV, telefonia móvel e banda larga. Em novembro de 2009, uma audiência pública na Comissão de Ciência e Tecnologia do Senado Federal externou este choque de concepções e a preocupação de que a alteração proposta pela ANATEL na faixa de 2,5 GHz geraria uma descompensação de forças no setor ao projetar um cenário de domínio das telecomunicações do país por operadoras móveis. A questão jurídica subjacente da legalidade da suspensão da certificação e homologação de equipamentos de telecomunicações para a

${ }^{3}$ A Associação Nacional das Operadoras Celulares (Acel) enviou carta à ANATEL em 2008 formalizando pleito para destinação integral da faixa de $2,5 \mathrm{GHz}$ destinada ao MMDS para o SMP.

${ }^{4}$ Seminário promovido pela Comissão de Ciência e Tecnologia, Comunicação e Informática, da Câmara dos Deputados, de 28 de maio de 2009. 
faixa de 2,5 GHz no aguardo de decisão do conselho diretor da ANATEL não foi esclarecida em 2009, presente apenas o posicionamento da procuradoria jurídica da ANATEL de que a suspensão seria ilegal, sob o argumento de que o ato seria vinculado à aprovação ou não dos pedidos de homologação ao invés de suspendê-los à espera de posicionamento do conselho. A questão jurídica vai além nesse caso ao tratar da competência do regulador e do formulador de políticas públicas. Ou seja, o argumento das operadoras móveis de que tais serviços ficariam inviabilizados sem a destinação da faixa para o SMP circunscrever-se-ia à competência regulatória da agência de administração do espectro ou dependeria de uma consulta ao formulador de política pública para definição de quais serviços teriam precedência na destinação de faixas de radiofrequência? Ao fim e ao cabo, os argumentos ad terrorem dominaram o cenário ao se projetar já para 2011 o limite para expansão do Serviço Móvel Pessoal (SMP), bem como a falência do sistema de telefonia móvel durante a Copa de 2014 e as Olimpíadas de 2016 caso não se mantivessem as alterações das faixas de MMDS para o SMP, muito embora já no início de 2010, a Casa Civil da Presidência da República tenha indicado, nos bastidores, que teria interesse em dedicar parte do espectro de 2,5 GHz para programas governamentais de expansão da banda larga. O processo de renovação das autorizações de MMDS no início de 2009 também sofreu com a indefinição sobre o destino da faixa de $2,5 \mathrm{GHz}$ e resultou em decisão polêmica do conselho diretor da ANATEL que, descartando - por considerá-la vaga - a recomendação da procuradoria jurídica de prorrogação excepcional por meio de outorga de autorizações especiais por prazo máximo de 24 meses até solução das questões pendentes, preferiu renovar as autorizações sem a definição imediata do valor pelo direito de uso de radiofrequência. Para as operadoras, o valor deveria ser o calculado nos moldes do Regulamento de Cobrança de Preço Público pelo Direito de Uso de Radiofrequência (Res. 387/07), enquanto a procuradoria jurídica da ANATEL afirmava a necessidade de se realizar estudo técnico e mercadológico recomendado pelo TCU para impedir "enriquecimento sem causa" das empresas. A ausência de uma definição sobre o valor do direito de uso de radiofrequência para as renovações do MMDS, bem como a persistência da indefinição sobre a divisão da faixa entre MMDS e SMP prometem fazer desse tema um dos temas centrais da agenda regulatória de 2010.

Revista de Direito, Estado e Telecomunicações, v. 2, n. 1, p. 1-44 (2010)

DOI: https://doi.org/10.26512/lstr.v2i1.21682 
O encolhimento do espectro também ficou patente na disputa antecipada sobre a destinação da faixa de $700 \mathrm{MHz}$, cuja liberação fora projetada no processo de transição da TV aberta analógica para a TV digital ${ }^{5}$ com prazo de migração total para 2016. Já no início de 2009, as operadoras móveis reforçaram a demanda pela destinação da faixa para solução das dificuldades projetadas de crescimento do SMP. Em resposta de abril de 2009, André Barbosa, assessor especial da Casa Civil responsável pelas questões relativas à TV digital, deu o recado ao setor de que nada havia sido definido sobre o assunto, de que a desvinculação da faixa da TV aberta não era fato consumado e de que, portanto, a faixa ainda seria da radiodifusão. Em maio de 2009, as radiodifusoras se pronunciaram abertamente contra a entrega da faixa de $700 \mathrm{MHz}$, pela voz do consultor da Abert e vicepresidente de relações institucionais das organizações Globo, Evandro Guimarães, que conclamou as radiodifusoras, durante o $25^{\circ}$ Congresso Brasileiro de Radiodifusão da Abert, a levarem para a Conferência Nacional de Comunicações a posição contra o dividendo digital (digital dividend), ou seja, contra o movimento mundial de atribuição das antigas frequências utilizadas pela radiodifusão analógica para a banda larga celular e outros serviços. $\mathrm{O}$ argumento então colocado à mesa foi o de que não se poderia permitir que um serviço público e gratuito perdesse banda para o serviço pago das telecomunicações, já que a faixa de $700 \mathrm{MHz}$ seria importante para a expansão da TV digital para pequenos municípios. Em outra frente, a Casa Civil, mediante participação de André Barbosa no Fórum WIMAX de junho de 2009, em Amsterdã, defendeu o uso do canal de retorno da TV digital na mesma frequência de $700 \mathrm{MHz}$, ancorado em análises da USP, Unicamp e Intel para expansão do padrão nipo-brasileiro de TV digital sem a necessidade de utilização das empresas de telecomunicações para a facilidade de canal de retorno, o que geraria maior atratividade mundial ao ISDB-T. Para tanto, André Barbosa tentou convencer os desenvolvedores do WIMAX a adaptarem o sistema para que funcionasse como canal de retorno da TV digital aberta no Brasil mediante integração do WIMAX ao chip do ISDB-T, utilizando a banda de $700 \mathrm{MHz}$ para retorno direto por meio do

${ }^{5}$ Vide Decreto 5.820, de 29 de junho de 2006, que adota o padrão ISDB-T para a TV aberta digital terrestre brasileira, bem como define as diretrizes para transição do sistema de transmissão analógica para o de transmissão digital.

Revista de Direito, Estado e Telecomunicações, v. 2, n. 1, p. 1-44 (2010) 
canal 1SEG próprio à transmissão para dispositivos móveis. A Casa Civil, portanto, prenunciou, em 2009, voltar atrás na posição de liberação da faixa de $700 \mathrm{MHz}$ para outros serviços em 2016. As TVs universitárias e comunitárias, por sua vez historicamente marginalizadas da ocupação do espectro da TV aberta, viram suas pretensões de consignação de canais digitais de $6 \mathrm{MHz}$ novamente postergadas quando o consultor jurídico do Ministério das Comunicações foi o porta-voz da posição da pasta de que a discussão de tais consignações somente seria possível quando da devolução dos canais analógicos em 2016, já que o ministério já teria feito um "esforço enorme" para acomodação dos quatro canais públicos, além da TV Senado, TV Câmara e TV Justiça. Como se pôde notar, a presença dos canais comunitários, componente fundamental da democracia participativa de nível local, continua ocupando uma posição periférica na política setorial. Em meio ao início das tensões sobre a efetiva destinação da faixa de $700 \mathrm{MHz}$ no Brasil de 2016, os Estados Unidos vivenciaram em 2009 a transição para a TV digital. Originalmente programada para 17 de fevereiro de 2009, o desligamento das transmissões analógicas de TV aberta nos Estados Unidos foi postergado para 12 de junho de 2009. A agência reguladora (Federal Communications Commission - FCC) foi obrigada a criar, ao apagar das luzes, um plano de preservação dos serviços de interesse público, exigindo das radiodifusoras que submetessem pedidos de desligamento à FCC para avaliação do interesse público. O padrão nipo-brasileiro de TV digital obteve, por sua vez, importantes conquistas em 2009, mediante a adesão da Argentina, Chile e Venezuela e a indicação do Paraguai e do Equador de que poderiam adotar o padrão ISDB-T. Em setembro de 2009 foi criado um fórum internacional para o padrão ISDB-T integrado inicialmente por Brasil, Japão e Perú, com presidência rotativa anual. Definido o padrão declarativo do middleware brasileiro do ISDB-T (Ginga-NCL) dependente de negociações posteriores sobre o Java, da Sun Microsystems, em maio de 2009 o Fórum SBTVD anunciou a decisão sobre a adoção do middleware para o sistema nipo-brasileiro como tendo uma arquitetura única dividida em dois subsistemas, quais sejam, a máquina procedural batizada de GingaJ, baseada no JavaDTV, e o ambiente declarativo Ginga-NCL. A produção de televisores e celulares com recepção no padrão ISDB-T também se consolidou em 2009, embora tenha sofrido com a decisão do Governo Federal de postergar as exigências dirigidas aos processos produtivos Revista de Direito, Estado e Telecomunicações, v. 2, n. 1, p. 1-44 (2010) DOI: https://doi.org/10.26512/1str.v2i1.21682 
básicos pertinentes aos percentuais de fabricação de celulares na Zona Franca de Manaus e em outros espaços industriais beneficiados por programas de incentivo fiscal. O Governo Federal também teve que enfrentar, em 2009, a contradição de promover o sistema nipo-brasileiro de TV digital sob os fundamentos de sua adoção (mobilidade, indústria nacional, multiprogramação, interatividade), de um lado, e de resistir às iniciativas da TV Cultura de São Paulo de transmissão em multiprogramação, de outro. Em fevereiro de 2008, a Fundação Padre Anchieta ingressou com pedido no Ministério das Comunicações de autorização para transmissão em multiprogramação, não obtendo resposta até que, em março de 2009, após decisão ministerial que considerou ilegal a transmissão de canais em multiprogramação por emissoras estaduais, da ameaça de início da transmissão mesmo na ausência de autorização ministerial, e de aceno de sanções por parte da ANATEL, a crise foi resolvida com a outorga ministerial de licença experimental à TV Cultura para multiprogramação. Em pronunciamento público de maio de 2009, o Ministro das Comunicações deixou claro o entendimento da pasta de que somente a União estaria autorizada a realizar multiprogramação, pois, sendo titular dos serviços de radiodifusão, não estaria vinculada às normas aplicáveis à concessão a terceiros. No aguardo de posição do legislador, o Ministério somente tem aceitado propostas de uso da multiprogramação em caráter científico ou experimental nos casos de canais de conteúdo educativo ou social. De fato, a TV Cultura iniciou a multiprogramação do canal educacional Univesp TV em 8 de junho de 2009. Em outro caso, o Grupo Abril entendeu desnecessário requerer autorização para multiprogramação ao realizar testes na frequência do Serviço Especial de TV por Assinatura em UHF (TVA). Em abril de 2009, o Grupo Abril desautorizou a Abert a falar em seu nome quando esta apoiou a ideia de que as radiodifusoras teriam se comprometido a usar toda a banda para transmissão em alta definição, tendo em vista que dita opção seria, na visão do diretor de canais do Grupo Abril, elitista e ineficiente: "não preciso de autorização, a autorização é o decreto [Decreto 5.820/06]". ${ }^{6}$

${ }^{6}$ LAUTERJUNG, Fernando. Abril diz que Abert não pode falar em nome da radiodifusão. TelaViva, 28 de abril de 2009. 
Toda a polêmica sobre quais serviços merecem ser beneficiados com a destinação de faixas de radiofrequência revolve um tópico adormecido mas sempre presente na regulação das telecomunicações relativo à opção por uma regulação por serviços e suas utilidades definidoras ou por tecnologia empregada na rede. Um julgamento de litígio de 2009 confirmou o papel decisivo desempenhado pela diferenciação jurídica de serviços e seus efeitos para o sistema de proteção do consumidor. Em maio, em decisão de primeira instância da justiça federal de Minas Gerais, duas empresas de telecomunicações foram proibidas de efetuar a venda casada de serviços de TV por assinatura e de banda larga com base na vedação contida no art. 39, do Código de Defesa do Consumidor. A ANATEL e as empresas defendiam que o serviço de acesso à internet seria adicional ao de TV por assinatura. Para o Ministério Público Federal, todavia, o serviço de acesso à internet seria serviço de telecomunicações, não se confundindo com o serviço de valor adicionado de contratação de provedor de conteúdo. Este caso, dentre inúmeros outros que lidam com as fronteiras classificatórias jurídicas de serviços, em especial no âmbito tributário, demonstram como o anúncio da convergência como um movimento inafastável não tem surtido efeitos no âmbito da conformação da classificação jurídica dos serviços de telecomunicações e seus resultados. Tal diagnóstico não surpreende, pois lida exatamente com o cerne da manutenção de tais fronteiras, na medida em que são comumente utilizadas para preservação de mercados por via regulatória. A esse respeito, em 9 de abril de 2009, a Telefônica respondeu a questionamento da ANATEL sobre a quebra da criptografia do acesso condicionado ao seu sinal de DTH, na medida em que era possível adquirir pela internet caixas de recepção com código de criptografia quebrado. As reclamações vieram de operadoras do sul do país, que alegavam concorrência desleal com essa recepção clandestina. O problema estava sendo administrado pela coordenação técnica do serviço de DTH da Telefônica sediada no Peru, mas sem sucesso. O questionamento formal da ANATEL induziu a Telefônica a apressar a troca dos smart cards de todos os antigos usuários. Esse caso demonstra como o esforço de manutenção das fronteiras regulatórias tem intrínseca relação com a manutenção de mercados via regulação, na medida em que o argumento de concorrência desleal é dependente das distinções regulamentares entre os serviços de DTH e o MMDS, e a vedação comum de que se equivalham à radiodifusão.

Revista de Direito, Estado e Telecomunicações, v. 2, n. 1, p. 1-44 (2010)

DOI: https://doi.org/10.26512/1str.v2i1.21682 
Essa dependência entre o formato regulamentar de definição de fronteiras dos serviços e a identificação dos mercados do setor de telecomunicações também restou patente no caso de acusações à disponibilização de conteúdo premium exibido na TV por assinatura em portais de internet dos próprios estúdios horas ou dias após sua exibição nos canais de TV por assinatura. Para a Net e a Sky, a atitude dos estúdios caracterizaria concorrência desleal, sob o argumento de que a cadeia de valor da indústria de mídia se iniciaria no cinema, passando pelo home-video, pelo pay-per-view, chegando, finalmente aos canais pagos de conteúdo premium, aos canais básicos da TV paga, para somente após isso chegar a TV aberta e à internet. Como a internet estaria predominantemente assentada em modelo de negócios baseado em publicidade, ela não poderia se colocar no mesmo espaço da TV paga na cadeia de valor da indústria de mídia.

O ano de 2009 também foi palco para o estatisticamente improvável, elevando a preocupação sobre a limpeza do espectro para o nível orbital. Dois satélites, um norte-americano e um russo, se chocaram em 11 de fevereiro de 2009, lançando mais de 500 destroços na órbita mundial com os consequentes riscos para outras posições orbitais.

Em março de 2009, por sua vez, nem mesmo satélites militares foram poupados da demanda por serviços, quando em operação da Polícia Federal intitulada "Satélite", foram apreendidos transceptores e antenas de fabricação caseira em Unaí, Minas Gerais, bem como a direção de dois satélites militares - o FLEETSAT-8 e o UFO -, possibilitando o uso de tais satélites para a realização de ligações telefônicas e acesso clandestino a canais de TV por assinatura em cidades de Minas Gerais, Santa Catarina, Mato Grosso, Mato Grosso do Sul e Tocantins.

$\mathrm{O}$ consumidor, o usuário e a sociedade tiveram o seu momento de estrelato no ano de 2009 para o bem ou para o mal. Foi o ano em que pela primeira vez, o Relatório de Gestão da ANATEL foi rejeitado ${ }^{7}$ pelo conselho consultivo da agência por 6 votos a 4 , sob o fundamento de inconsistências no relatório e nas dificuldades da agência em atender as demandas da sociedade.

No tocante ao esforço governamental de expansão do acesso à banda larga, o Convênio CONFAZ n. 38, publicado no DOU de 8 de abril de 2009,

${ }^{7}$ Votação no conselho consultivo da ANATEL de 21 de agosto de 2009.

Revista de Direito, Estado e Telecomunicações, v. 2, n. 1, p. 1-44 (2010) DOI: https://doi.org/10.26512/1str.v2i1.21682 
autorizou a possibilidade de isenção do ICMS para o serviço de comunicação de acesso à banda larga no âmbito do Programa Internet Popular, desde que o serviço não ultrapassasse $\mathrm{R} \$ 30,00$ mensais já embutido o preço dos equipamentos utilizados, como o aluguel do modem. Em dezembro de 2009, a Net inaugurou a prestação de serviços de banda larga popular no Estado de São Paulo.

Também em 2009, provocados pelo Comitê Gestor da Internet (CGI.br) e pelo Instituto de Defesa do Consumidor (Idec), a ANATEL e a Rede Nacional de Pesquisa (RNP) iniciaram tratativas para oferecerem um serviço que auxiliasse o usuário a comparar a qualidade dos serviços de banda larga oferecidos no país.

O ano de 2009 foi o ano de aprovação da Lei 11.934, de 5 de maio, que se inseriu na disputa federativa no tocante à regulamentação estadual e municipal de emissões eletromagnéticas, mas contemplada com veto presidencial a dispositivo que previa a destinação de $1 \%$ das verbas do Fistel para que a ANATEL fizesse pesquisas de emissões radioelétricas.

Sob o fundamento de proteção dos direitos do consumidor mediante esclarecimento das responsabilidades das operadoras de telecomunicações e provedores de serviços de acesso à internet, o ano de 2009 também presenciou o avanço da ANATEL na regulamentação indireta dos serviços de valor adicionado (SVA) quando, no âmbito da regulação da relação entre provedores e operadoras de telecomunicações, voltou-se à garantia de índices mínimos de qualidade e segurança do acesso à internet mediante licitação de proposta de instituição de um sistema de monitoramente remoto das redes de cada uma das prestadoras de telecomunicações para identificação da origem das falhas: se nas redes das operadoras ou nos provedores.

Finalmente, a novela do ponto extra da TV por assinatura, cujo enredo se resumia à possibilidade ou não de sua cobrança, foi decidida pela ANATEL, embora persistam dúvidas sobre os efeitos da decisão. O grupo de trabalho criado pela presidência da agência para o fim de emitir estudo técnico sobre o tema chegou às mesmas conclusões do $\mathrm{CPqD}$ em estudo encomendado pela ABTA, afirmando, em análise concluída em 20 de fevereiro de 2009, existirem custos fixos, recorrentes e incrementais surgidos de cada novo ponto extra instalado. Com o enfraquecimento da tese da gratuidade do ponto extra defendida por associações de defesa do consumidor, em 17 de Revista de Direito, Estado e Telecomunicações, v. 2, n. 1, p. 1-44 (2010) DOI: https://doi.org/10.26512/lstr.v2i1.21682 
abril de 2009, o conselho diretor da agência aprovou a Resolução n ${ }^{\circ} 528$, que dispôs sobre a redação final dos dispositivos pertinentes do regulamento de proteção dos direitos dos assinantes de televisão por assinatura. A decisão firmada impede a cobrança recorrente mensal sobre o serviço de ponto extra, mas permite a cobrança pela instalação e pelo aluguel do equipamento, que é um evento passível de cobrança desde que discriminado na fatura. Estimou-se, nas razões de decidir do conselho diretor, o valor de $\mathrm{R}$ \$ 350,00 a R \$ 370,00 como custos razoáveis de instalação. A principal empresa que discutia a legalidade de proibição de cobrança pelo ponto extra (Net Serviços) optou, em julho de 2009, por não estender a discussão judicial, retomando a instalação de pontos extras com redução do valor de $\mathrm{R} \$ 24,90$ para $\mathrm{R} \$ 19,90$ por ponto e enquadrando-se na determinação da ANATEL de proibição de venda de ponto extra vinculado à programação, na medida em que passou a cobrar pelo "aluguel de equipamento adicional", além de abrir a possibilidade de compra do equipamento à vista por quem quisesse fazê-lo pelo valor de $\mathrm{R} \$ 1.500,00$ e de suspensão da cobrança do pay-per-view por ponto, liberando o pacote para todos os conversores instalados na residência. A representação dos consumidores, entretanto, não ficou satisfeita com a solução, encaminhando à ANATEL, em julho, solicitação de que se regulamentasse a cobrança de manutenção ou aluguel do ponto extra. Em 14 de julho de 2009, a Fundação Procon-SP divulgou nota considerando a cobrança de aluguel pelo ponto extra como "uma evidente e escancarada tentativa de driblar a norma, mascarando a cobrança pelo ponto extra e prejudicando os consumidores" na medida em que a cobrança deveria estar limitada a evento comprovado de instalação e reparo, segundo a regulamentação da ANATEL. Ao que tudo indica, novos capítulos dessa novela ocuparão o cenário do setor com direito a anos de exibição no Judiciário.

Digno de nota foi a comemoração da plena extensão da portabilidade numérica prevista pela Resolução $\mathrm{n}^{\circ}$ 460, de 19 de março de 2007, e instaurada a partir de $1^{\circ}$ de setembro de 2008 progressivamente segundo os códigos geográficos brasileiros. Em março de 2009, todos os códigos geográficos foram alcançados pela portabilidade numérica com quase 5 milhões de pedidos de portabilidade em serviços fixos e móveis e cerca de 3,8 milhões de números efetivamente portados no início de 2010, segundo 
dados da entidade administradora da portabilidade numérica no Brasil, a ABR Telecom.

O procedimento e as audiências públicas para a revisão quinquenal dos contratos de concessão mantiveram-se discretos no contexto das demais questões de interesse do setor, resguardando-se para o provável acirramento dos debates em 2010. Dentre os pontos discutidos em 2009 para revisão dos contratos de concessão e para a correspondente regulamentação complementar, encontram-se: a possibilidade de alteração das regras referentes aos processos de telefonia, em especial o limite de $64 \mathrm{kbit} / \mathrm{s}$ sob o fundamento de que em todos os demais serviços de telecomunicações, a banda larga é considerada apenas uma funcionalidade e não um serviço a parte; a possibilidade de uso de tecnologias que permitam a redução dos custos do serviço de voz para cada segmento de assinantes; a permissão de autenticação pela prestadora de telecomunicações; o detalhamento de critérios de mobilidade restrita; a incorporação de prestação, utilidade ou comodidade (PUC) no plano de serviço do assinante; a revisão de regras referentes à fidelização; a previsão de regras de estímulo ao uso de faixas de frequências, inclusive em caráter secundário, em regiões de baixa atratividade econômica; a flexibilização dos critérios de qualidade, com enfoque na qualidade percebida pelo usuário, permitindo-se a diferenciação por segmento de assinantes, de planos de serviços ou de regimes de exploração; a ampliação das áreas locais; a revisão das regras do acesso individual classe especial (AICE); a maior transparência aos usuários dos planos de serviço e de prestações, utilidades e comodidades (PUCs); a liberdade tarifária na longa distância nacional (LDN) e internacional (LDI); a aplicação do Fator X em planos alternativos; a revisão dos critérios de remuneração de rede, visando à convergência de redes e serviços e estímulo de uso de redes interconectadas; a alteração das regras de acompanhamento de controle dos bens reversíveis; o detalhamento do nível de remuneração dos investimentos relacionados a bens, atividade e processos essenciais à prestação do STFC em regime público; a implementação do Plano Geral de Metas de Competição (PGMC); a revisão do processo de fiscalização, acompanhamento e controle do cumprimento de obrigações, no que se refere aos procedimentos internos da agência; além das temáticas objeto da anuência prévia para aquisição da Brasil Telecom pela Oi e daquelas 
presentes no Plano de Geral de Atualização da Regulamentação das Telecomunicações no Brasil (PGR).

Em certa medida, o ano de 2009 caracterizou-se como um ano de solução de assuntos pendentes, como o do caso Serpro. Em 16 de abril de 2009, o conselho diretor da ANATEL decidiu por 3 votos a 1 anular a renúncia do Serpro à autorização de Serviço de Comunicação Multimídia (SCM) com fundamento no interesse público, resultando no dever do Serpro de recolhimento de todos os tributos setoriais (FUST, FUNTTEL e FISTEL). A posição do Serpro, quando da renúncia, era a de que ele não exercia serviço de comunicação de dados, mas de processamento de dados e, que, por isso, não necessitaria da autorização de SCM. A renúncia permitiu que o Serpro economizasse no pagamento de ISS sobre serviços de tecnologia da informação (TI) ao invés da incidência do ICMS sobre serviços de telecomunicações.

Entretanto, nenhum acontecimento foi mais marcante e representativo para a sociedade do que a instabilidade do serviço de banda larga da Telefônica no Estado de São Paulo conhecido como a pane da banda larga no serviço chamado Speedy. O ocorrido esgarçou a confiança sobre o modelo regulatório no que se refere ao acompanhamento da qualidade da infraestrutura física e gerencial dos serviços. A pane em São Paulo atingiu a rede de banda larga da Telefônica no final do primeiro semestre de 2009 e foi seguida, em 2 de julho, de recomendação do Ministério Público Federal à Telefônica e à ANATEL, de que se aceitasse o cancelamento dos contratos de serviços de internet do Speedy sem aplicação das consequências da cláusula de fidelização em razão da incapacidade da Telefônica de manutenção da qualidade contratada. Por 90 dias, a partir de 6 de julho de 2009, a Telefônica suspendeu a multa pelo cancelamento do serviço. Na esfera regulatória, suspensa a sua comercialização por decisão cautelar do conselho diretor da ANATEL a partir de 23 de junho de 2009, a venda do Speedy somente voltou a ser autorizada em reunião de 26 de agosto de 2009 para, em 8 de setembro de 2009, ocorrer uma nova pane agora na rede de voz da Telefônica, quando um conjunto de oscilações na rede provocou dificuldades no completamento de chamadas para usuários da capital e cidades da Grande São Paulo, inclusive em serviços de emergência da Política Militar (190) e do Corpo de Bombeiros (193). Atribuíram-se às chuvas os problemas na rede da Telefônica enquanto a Embratel declarava 
não ter experimentado problemas em sua rede no mesmo período, o que deu ensejo à abertura de processo, na Comissão de Valores Mobiliários do Rio de Janeiro (2009/8460), por parte da Associação dos Engenheiros de Telecomunicações (AET) para investigação dos investimentos feitos pela Telefônica, sob a acusação de não ter investido o que havia sido declarado nos anos de 2008 e 2009 para ampliação e modernização da sua rede. A mesma associação questionou o BNDES sobre empréstimo à Telefônica de 2 bilhões de reais, em 2007, e o monitoramento dos investimentos dele esperados. Em 9 de setembro de 2009, a Trópico, uma joint venture entre a Promon e o $\mathrm{CPqD}$, emitiu comunicado de responsabilidade pela pane da Telefônica, alegando que três equipamentos de sinalização de rede teriam sido seriamente afetados por descargas elétricas da tempestade atípica do dia 8 de setembro, algo que não impressionou as associações de consumidores, haja vista a responsabilidade regulamentar da operadora de telecomunicações sobre a qualidade dos serviços. As redes móveis 3G também não fugiram às críticas, tendo sido ameaçadas por cartas da Gerência Especial de Comunicações Pessoais Terrestres da ANATEL de sofrerem o mesmo destino de suspensão de serviços do Speedy da Telefônica caso os serviços 3G das quatro grandes operadoras não fossem incrementados, levando, inclusive, à proposta daquela gerência de autonomia dos serviços de voz e dados mediante separação entre as estações rádio base (ERB) de $2 \mathrm{G}$ e $3 \mathrm{G}$ para garantia de que se os serviços $3 \mathrm{G}$ fossem afetados, não prejudicassem as chamadas de voz. A tão propalada fungibilidade entre serviços de dados e voz também sofreu outro revés em 2009, quando em agosto, o Ministério das Comunicações anunciou que realizaria estudos para avaliar a equivalência de custos das metas de universalização na troca dos postos de serviços de telecomunicações (PST) por obrigações de infraestrutura de rede de suporte do STFC (backhaul), haja visto o desencontro entre as projeções de gastos das empresas para implementação das novas metas de redes de banda larga ( $\mathrm{R} \$ 13$ bilhões) e os estudos iniciais da ANATEL ( $\mathrm{R} \$ 1$ bilhão). O tema enfatizado no ano de 2008 pela associação de defesa do consumidor Pro Teste de preservação dos interesses do consumidor de serviço telefônico e a possibilidade de que o consumidor fosse onerado pelo financiamento da expansão da banda larga permanece, portanto, em voga. 
Outros acontecimentos sobre a banda larga foram dignos de nota, como a longa espera pela regulamentação da utilização das instalações de distribuição de energia elétrica para a banda larga expressa nas siglas inglesas PLC (Power Line Communication) e BPL (Broadband over Powerlines). A ANATEL aprovou a Resolução $\mathrm{n}^{\circ}$ 527, de 8 de abril de 2009, que veiculou o "Regulamento sobre Condições de Uso de Radiofrequências por Sistemas de Banda Larga por meio de Redes de Energia Elétrica" (1705 kHz a $50 \mathrm{MHz})$ com intensa preocupação de preservação do Serviço Móvel Aeronáutico, do Serviço Móvel Marítimo, do radioamador, e da radiodifusão de sons e imagens contra interferência prejudicial, na medida em que se mantém o uso primário nas correspondentes frequências. Nela, exigiu-se a presença de sistema para desligamento remoto do serviço caso cause interferência prejudicial nos demais serviços de telecomunicações, bem como se vedou a sua utilização nas faixas de proteção de estações terrestres de $1705 \mathrm{kHz}$ a $30 \mathrm{MHz}$, exigindo-se o fornecimento de dados para a ANATEL com a finalidade de manutenção de base de dados pública sobre os locais de uso da tecnologia. Não tardou para que as radiodifusoras reagissem em maio de 2009, em conferência da Abert, acusando-se o PLC de interferir nos sinais de ondas curtas. A ANEEL, por sua vez, aprovou, em 25 de agosto de 2009, a Resolução Normativa $n^{\circ} 375$, disciplinando a utilização das instalações de distribuição de energia elétrica como meio de transporte para a comunicação digital e analógica de sinais.

Como era de se esperar, a troca das obrigações de universalização de Postos de Serviços de Telecomunicações (PST) por infraestrutura de rede de suporte do STFC (backhaul) persistiu em 2009 como um tópico em pauta e, em março ninguém menos que o primeiro presidente da ANATEL, atuando como consultor privado, defendeu que o backhaul não seria essencial à fruição do STFC em resposta à provocação da Procuradoria da República, que sugerira, em discussão no conselho consultivo da ANATEL, que, em face da evolução dos serviços de telecomunicações, talvez já fosse o momento de se repensar se o "T" de STFC seria telefonia ou telecomunicações. Por sua vez, a associação de defesa do consumidor Pro Teste defendeu a natureza privada da infraestrutura do backhaul, enquanto a Oi defendeu a natureza pública da infraestrutura como essencial ao STFC nas discussões abertas pelo conselho consultivo da ANATEL. Digno de nota 
foi a afirmação do presidente da Abrafix, José Fernandes Pauletti, de que seria necessário ampliar o escopo do regulamento de bens reversíveis (Res. 447/06) para que ele atingisse não somente bens físicos e patrimônio associados à concessão, mas também a infraestrutura cuja essencialidade ao serviço é mais sutil, advogando, portanto, pela redefinição de bem reversível segundo um critério não físico e estático, mas vinculado à necessidade de continuidade do STFC. Para compreensão deste posicionamento da Abrafix, é importante ter-se em mente que a associação enviou carta à ANATEL solicitando a retirada da anuência prévia para desvinculação, alienação e substituição de bens reversíveis e para a celebração, alteração e rescisão de contratos com terceiros por parte de concessionária de STFC. Trata-se, portanto, de proposta de alteração conceitual de bens reversíveis para desoneração burocrática da empresa no manuseio dos bens afetos ao serviço, deixando à regulação a função de definir tais bens no futuro. Além disso, a consequência de se definir o bem reversível como exclusivamente aquele essencial à prestação de STFC é reduzir drasticamente a responsabilidade direta da concessionária sobre a operação de componentes da rede, e em acréscimo, definitivamente destacar as obrigações de serviço universal da prestação de banda larga. ${ }^{8}$ Em meio à polêmica sobre a indefinição da natureza jurídica da infraestrutura de rede de suporte ao STFC (backhaul) e sob a ameaça do julgamento de ação proposta pela Pro Teste em 2008, que entendia ilegal a troca de metas de universalização do PST para uma rede cuja natureza jurídica seria privada, o conselho diretor da ANATEL aprovou proposta de termo aditivo para assinatura pelas concessionárias, definindo expressamente o backhaul como bem reversível. A assinatura efetiva do aditivo aos termos de Serviço de Comunicação Multimídia (SCM) das concessionárias ocorreu em 15 de maio de 2009, prevendo-se, expressamente a reversibilidade do backhaul, e publicados em 4 de junho de 2009 no Diário Oficial da União.

${ }^{8}$ Em declaração de agosto de 2008, o presidente da Oi declarava quanto à futura devolução dos bens reversíveis ao Estado que estes corresponderiam a $1 \%$ da rede da operadora: "Vou devolver o que eu posso: as centrais, o fio de cobre... É isso".

Revista de Direito, Estado e Telecomunicações, v. 2, n. 1, p. 1-44 (2010)

DOI: https://doi.org/10.26512/lstr.v2i1.21682 
A regulamentação do backhaul prevista para agosto de 2008 ainda não foi aprovada em 2009. ${ }^{9} \mathrm{O}$ ano foi inaugurado com o reconhecimento de que a Oi encontrava-se atrasada no cronograma de implantação do backhaul. Dos 1092 municípios exigidos para 2008 pelo Decreto 6.424/08, a Oi somente havia levado o backhaul a 561, respondendo a procedimento administrativo para apuração de descumprimento de obrigações (PADO) aberto e notificado no início de 2009. É bem verdade que no que toca a obrigações de universalização, a Oi detém uma posição diferenciada em termos de cobertura. Mesmo assim, 2009 foi encerrado com a declaração de cumprimento dos compromissos de expansão do backhaul por todas as operadoras de telefonia fixa. Os dois últimos meses do ano foram responsáveis pela instalação de $48 \%$ da meta de backhaul para o ano de 2009, saltando de 1.430 municípios, em outubro, para 2.772 municípios ao finalizar o ano, na proporção de 2.184 municípios atendidos pela Oi. Antes da edição do Decreto 6.424/08, das 5.564 sedes municipais brasileiras, somente 2.125 detinham infraestrutura de banda larga. Assim, para o ano de 2010 restam 667 municípios não atendidos. No que se refere ao Projeto Banda Larga nas Escolas, as empresas informaram terem cumprido as metas definidas para 2008 e 2009, alcançando 43.193 escolas conectadas à banda larga em 31 de dezembro de 2009: 22.684 pela Oi; 2.333 pela Telefônica; 232 pela CTBC; e 82 pela Sercomtel.

Nem tudo se resumiu a ajustes de políticas já implementadas para a banda larga. $\mathrm{O}$ ano de 2009 se caracterizou pela cobrança por uma definição mais precisa do papel da banda larga na política de telecomunicações, mediante a confluência de atuações de órgãos ligados à Presidência da República e de provocações do Congresso Nacional e da sociedade civil. Em maio de 2009, o deputado Paulo Henrique Lustosa apresentou à Mesa da Câmara dos Deputados indicação para encaminhamento ao Ministro das Comunicações e ao presidente da ANATEL, sugerindo a formulação de uma política nacional de banda larga, com o correspondente plano de metas de

${ }^{9}$ O Plano Geral de Metas de Universalização (PGMU II) voltado à regulamentação do backhaul foi finalmente aprovado em 11 de fevereiro de 2010, pelo conselho diretor da ANATEL. Ele declara que o backhaul público, ou seja, o gerado pela troca das metas de instalação de Postos de Serviços de Telecomunicações (PST) por infraestrutura de rede de suporte ao STFC (backhaul), é um bem reversível.

Revista de Direito, Estado e Telecomunicações, v. 2, n. 1, p. 1-44 (2010) 
universalização, reclamando da inação do Ministério das Comunicações a esse respeito, pois a consulta pública lançada em abril de 2008 sobre políticas públicas de telecomunicações, embora tivesse recebido diversas contribuições não se consubstanciara em um documento final de orientação do setor.

A banda larga rural ocupou posição de destaque, por sua vez, em seminário da Comissão de Ciência e Tecnologia, Comunicação e Informática da Câmara dos Deputados, de 28 de maio de 2009, em que o Secretário de Telecomunicações do Ministério das Comunicações, Roberto Pinto Martins, ressaltou que se estaria elaborando uma política de banda larga para áreas rurais, utilizando-se da faixa de $450 \mathrm{MHz}$. A ANATEL, em junho de 2009, anunciou que iniciaria o trabalho de limpeza das faixas de 225 a $270 \mathrm{MHz}, 360$ a $380 \mathrm{MHz}, 380$ a $400 \mathrm{MHz}$ e 450 a $470 \mathrm{MHz}$ para antecipar as providências necessárias à implantação da política pública já anunciada pelo Ministério das Comunicações de expansão da banda larga para escolas públicas rurais, destinando a faixa de $450 \mathrm{MHz}$ para a telefonia fixa e móvel rural, com tecnologia sem fio.

Um novo ator governamental de peso apresentou-se, em 2009, como mais um componente da formulação da política pública do setor de telecomunicações. A Secretaria de Assuntos Estratégicos da Presidência da República elegeu as telecomunicações como uma de suas ações de planejamento estratégico, celebrando sua inserção na equipe de coordenação do Plano Nacional de Banda Larga mediante evento internacional de agosto de 2009 intitulado "Alternativas para o Desenvolvimento da Infraestrutura e do Acesso em Banda Larga" e realizado no BNDES em Brasília, em que o representante da Casa Civil, César Alvarez, acenou com a necessidade de se reinserir no sistema de telecomunicações o subsídio cruzado para viabilização da universalização da banda larga. O papel de destaque do Coordenador dos Programas de Inclusão Digital da Presidência da República, César Alvarez, na elaboração do Plano Nacional de Banda Larga restou claro no segundo semestre de 2009, antecipando, em suas aparições públicas, certos pontos-chave da proposta que, após algumas postergações, foi finalmente apresentada ao Presidente Lula com o reconhecimento da importância da Telebrás e dos ativos da Eletronet para reafirmação da responsabilidade estatal pela universalização de acesso à banda larga. Exigindo maturação em certos pontos de ordem tributária e de cenários de Revista de Direito, Estado e Telecomunicações, v. 2, n. 1, p. 1-44 (2010)

DOI: https://doi.org/10.26512/1str.v2i1.21682 
participação estatal e custos, o anúncio do Plano Nacional de Banda Larga foi postergado para 2010. Em paralelo, as grandes operadoras de telefonia firmaram, ao final do $53^{\circ}$ Painel Telebrasil, o que denominaram de Carta do Guarujá, com posições consolidadas de discussões sobre banda larga e políticas setoriais, propondo um plano nacional de banda larga para que se alcançasse, em 2014, 75\% de penetração ou 150 milhões de usuários, esperando-se com isso sensibilizar o governo sobre os pontos sensíveis de desoneração tributária, redefinição de competências federais, estaduais e municipais para implantação de infraestrutura, adequação de regras de custos de direitos de passagem, oferta de novas outorgas para prestação de serviços com a eliminação de restrições de acesso ou origem de capital, bem como alocação de novas faixas de frequência de modo a se evitar prejuízo a concorrentes estabelecidos em condições mais onerosas. Sob o enfoque das propostas da Telebrasil na Carta do Guarujá, o encolhimento do espectro seria uma decisão regulatória de preservação de condições isonômicas de ingresso no mercado de telecomunicações brasileiro e de preservação de expectativas de retorno de investimento por parte das empresas incumbentes. ${ }^{10}$ A carta é clara também em dizer que o Plano Nacional de Banda Larga e as políticas públicas deveriam caminhar para terem sua implementação conduzida pelas empresas privadas.

O registro das notícias do setor demonstra como o ano de 2009 foi caracterizado como um ano de crise da banda larga tanto em termos práticos de problemas de tráfego nas redes das operadoras, quanto em termos jurídicos de evidência da desestruturação normativa e forte caráter divergente da normatização setorial em termos de largura de banda e de mobilidade; foi um período de falhas operacionais em larga escala, de atuação da ANATEL na venda de serviços de banda larga e exigência de submissão de plano empresarial para superação da crise da Telefônica, bem como de acusações dos consumidores tanto de uso indevido da infraestrutura reservada ao STFC em banda estreita quanto de má prestação do serviço de banda larga em si mesmo. Na primeira semana de novembro

${ }^{10}$ É sintomático que, em 2009, na França, a operadora France Telecom tenha se indignado com a oferta de uma quarta licença de $3 \mathrm{G}$ por um preço mínimo inferior ao praticado para a sua licença, alegando que isso caracterizaria auxílio ilegal à nova entrante. 
de 2009, o Instituto de Defesa do Consumidor (Idec) divulgou estudo crítico à qualidade dos serviços de banda larga do país, com enfoque nas promessas das operadoras de planos ilimitados e em propagandas enganosas, revelando, nas respostas das operadoras nacionais (Oi, Claro, Vivo e TIM), o argumento de que a contratação de serviços ilimitados diria respeito unicamente ao volume de tráfego e não à velocidade contratada pelo usuário. Enfim, esse conjunto de acontecimentos revela a crescente centralidade da banda larga em termos de percepção social da importância do serviço, o que não passou despercebido pelo governo, quando em reunião de apresentação da proposta do Plano Nacional de Banda Larga (PNBL), de 24 de novembro de 2009, o presidente Lula solicitou estudos de estimativa do custo para o Estado brasileiro da oferta direta de acesso banda larga e não somente de oferta de capacidade de rede no atacado mediante organização de backbone nacional complementar ao das operadoras de telecomunicações. O quarto trimestre de 2009 deixou claro que a proposta de PNBL defendida pela Casa Civil, SAE, Ministério do Planejamento, dentre outros partícipes ${ }^{11}$, era de uso das redes da Eletronet, Petrobrás, e empresas de energia para oferta de backhaul e backbone em áreas onde as operadoras de telecomunicações não chegassem ou onde não houvesse concorrência, bem como para atendimento das necessidades de rede do próprio Governo Federal. Os obstáculos jurídicos para o uso da rede da Eletronet demandaram a atenção da equipe de proposição do PNBL, dentre eles: esclarecimento dos direitos de passagem com a Eletronorte e a Chesf; passivo com a Furukawa estimado em R $\$ 220$ milhões; e passivo com a Alcatel-Lucent estimado em $\mathrm{R} \$ 160$ milhões. ${ }^{12}$ A intenção governamental,

${ }^{11}$ Embora não pelo Ministério das Comunicações, aquele que, pelo menos nominalmente, é o órgão central responsável, em primeira instância, pelas políticas públicas setoriais.

${ }^{12}$ Desde 2003, encontra-se em tramitação o processo de falência da Eletronet. De um lado, a Chesf, Eletronorte e Eletrosul demandando a devolução dos ativos que cederam à Eletronet. De outro lado, os credores como a Furukawa e Alcatel-Lucent exigindo que se salde a dívida deixada pela Eletronet. Como controladoras da Eletronet estão a Lightpar, da União, e a LT Bandeirante, sócio privado com 51\% das ações. Em março de 2009, boatos de que a Oi estaria interessada em adquirir a Eletronet fizeram disparar os preços das ações da Oi na bolsa de valores, mas logo foram desmentidos sob o argumento de que todas as grandes prestadoras do país Revista de Direito, Estado e Telecomunicações, v. 2, n. 1, p. 1-44 (2010)

DOI: https://doi.org/10.26512/1str.v2i1.21682 
entretanto, foi gestada em um ambiente adverso. Em 27 maio de 2009, a Comissão de Ciência e Tecnologia, Comunicação e Informática, da Câmara dos Deputados, aprovou requerimento do deputado Paulo Bornhausen (DEM/SC) para avaliar a intenção do governo federal até então vagamente esboçada de reativação da Telebrás para gestão do backbone de fibra óptica da Eletronet, acusando-a de se configurar em possível interferência na competitividade e na geração de empregos públicos e privados do setor, bem como de possível afronta ao art. 173 da Constituição Federal. Em junho de 2009, a Casa Civil encaminhou pedido formal à ANATEL para que fossem devolvidos à TELEBRÁS 50 funcionários. Em julho de 2009, o discurso de reativação da sociedade de economia mista já se concentrava na utilização das redes da Petrobrás e de Furnas como ponto de partida, com o objetivo de se desconectar a iniciativa de reativação da Telebrás da solução judicial do passivo da Eletronet. O discurso governamental, em meados de 2009, ainda se concentrava na criação de uma "grande rede de comunicação governamental”, embora, nos bastidores, já antecipasse a expectativa de servir para ampliar a universalização da banda larga para inclusão digital. Em 31 de julho de 2009, o presidente Lula externou o objetivo de se utilizar a rede da Eletronet para universalização da banda larga no Brasil ao lamentar a dificuldade que o governo estava tendo em recuperar a rede na Justiça. ${ }^{13}$ Em 5 de agosto, o TJRJ acolheu liminarmente agravo apresentado pela Companhia Hidroelétrica do São Francisco (Chesf), determinando que a cessão da rede da Eletronet às estatais de energia já decidida no ano anterior não dependeria da análise do mérito dos recursos pendentes no processo de falência da Eletronet. Em 16 de novembro, em evento internacional voltado a angariar contribuições internacionais (África do Sul, Canadá, EUA, Nova Zelândia, Sri Lanka, Suécia e Japão) ao PNBL, promovido pela Secretaria de Assuntos Estratégicos da Presidência da República, em Brasília, serviu como palco para a primeira apresentação em público das linhas gerais da proposta do grupo de trabalho criado pelo

analisam todos os anos a possibilidade de aquisição da Eletronet, mas devido ao montante dos passivos e do custo de adaptação da rede à exploração comercial, não chegam a concretizar a operação.

${ }^{13}$ Teletime. Lula quer Eletronet para "levar banda larga para onde a gente quiser", sexta-feira, 31 de julho de 2009. Reportagem de Mariana Mazza.

Revista de Direito, Estado e Telecomunicações, v. 2, n. 1, p. 1-44 (2010) DOI: https://doi.org/10.26512/1str.v2i1.21682 
presidente Lula para formulação de proposta do PNBL. Nessa ocasião, César Alvarez rebateu as críticas endereçadas ao PNBL, declarando ser "anacrônico e preconceituoso que o governo não possa usar os seus ativos de redes de fibras ópticas", e o formato de exploração da rede a fórum a ser criado entre empresas e governo. Em 26 de novembro de 2009, os acionistas da Telebrás, em Assembleia Geral Extraordinária, homologaram aumento de capital social da empresa aprovado em 19 de fevereiro de 2009, de $\mathrm{R} \$ 219,4$ milhões para R \$ 419,4 milhões. O ano foi marcado por declarações de fontes governamentais envolvidas no tema. Dentre elas, Rogerio Santanna, Secretário de Logística e Tecnologia da Informação do Ministério do Planejamento, defendeu a existência de uma rede estatal de banda larga, pois o Brasil precisaria de uma rede neutra para "democratização da distribuição".

Ainda no que diz respeito à infraestrutura do setor, o tema adormecido do direito de uso das caixas de passagem presentes no imóvel do consumidor/usuário afloraram em Salvador, quando a Oi passou a cobrar preço privado de $\mathrm{R} \$ 359,00 /$ mês de operadora de TV por assinatura (TV Cidade), em abril de 2009, pelo uso de cada caixa de passagem em condomínios, sob o fundamento de propriedade sobre tais caixas. A Associação Brasileira de TV por Assinatura (ABTA) reagiu à medida, emitindo nota segundo a qual as caixas de passagem e as redes internas seriam da jurisdição dos condomínios. A tensão sobre os direitos de uso de caixas de passagem se firmou na disputa entre as operadoras Oi/BrT e GVT. Em 16 de abril, o TRF $1^{a}$ Região, sob a relatoria do desembargador João Batista Moreira, determinou que a ANATEL teria 48 horas para decidir liminarmente e 10 dias para decidir o mérito sobre quem seria o legítimo proprietário da infraestrutura dos acessos prediais de Salvador e de todas as outras instalações do país onde ambas as operadoras compartilhavam cabos. Em 15 de maio de 2009, GVT e Oi protocolizaram na Anatel acordo resultado de conciliação na Gerência-Geral de Competição da Superintendência de Serviços Públicos da ANATEL com o objetivo de por fim à disputa judicial, concordando em ratear o custo de manutenção das caixas de passagem (armário de linhas prediais para conexão final dos consumidores) estimada para a cidade de Salvador em $\mathrm{R} \$ 0,70$ por edificação, como também concordaram em abandonar a discussão sobre a propriedade ou posse das caixas de passagem. Adotou-se o termo 
"mantenedora" para identificar quem seria o responsável pela manutenção do equipamento, arcando com os custos até o momento. O gerente-geral de competição da SPB, José Gonçalves Neto, explicou à época que o uso das caixas de passagem seria da família dos "usos compartilhados, do qual fazem parte as linhas dedicadas, o co-faturamento, a desagregação de redes".

No que se refere a fusões e aquisições no período, o ano de 2009 foi palco de movimentações cinematográficas para aquisição de controle acionário da empresa espelho mais exitosa do país - a GVT - revelado na disputa entre a Telefônica e a francesa Vivendi, que foi acompanhada pelo setor com a atenção despertada pela possibilidade de ingresso de um novo grande competidor internacional no cenário de competição de redes de telefonia e banda larga. Na primeira quinzena de novembro de 2009, o avanço nas ofertas para compra de ações da GVT apontavam para a concretização da aquisição por parte da Telefônica, gerando até mesmo reação da Pro Teste, que, incontinente, enviou comunicado à Ministra Chefe da Casa Civil, Dilma Rousseff, alertando para o risco de lesão ao consumidor advindo de eventual aquisição da GVT pela Telefônica, haja vista o possível repasse dos custos de aquisição da operação aos consumidores, a falta de mecanismo da agência reguladora para acompanhamento desse repasse, e a notória deficiência do serviço da Telefônica em São Paulo no ano de 2009. Em 12 de novembro de 2009, foram aprovadas, no conselho diretor da ANATEL, as anuências prévias à compra da GVT pela Telefônica e pela Vivendi, inexistindo condicionamentos para o caso da Vivendi e presentes um conjunto de condicionamentos no caso de compra pela Telefônica para proteção da concorrência, impondo-se, pela primeira vez na história da ANATEL, a exigência de que a GVT e a Telefônica permanecessem com suas estruturas administrativas, operacional, funcional e comercial, inclusive marcas, separadas pelo período de cinco anos, inexistentes, entretanto, esclarecimentos sobre como tal determinação seria equacionada com a exigência de eliminação de sobreposições de licenças e autorizações em até 18 meses após a concretização de negócio que envolva sobreposições de autorizações de uso de radiofrequência e código de seleção de prestadora. Também foram impostos outros condicionamentos ligados à transparência das ofertas de serviços, neutralidade de rede e nível de emprego após a 
operação. Em paralelo a esse processo de condicionamentos e cuidados governamentais sobre a anunciada aquisição da GVT, a Vivendi superou a oferta da Telefônica e fechou o acordo com os controladores da GVT para compra de sua participação na GVT em 13 de novembro de 2009 com a oferta de R \$ 55,00 por ação, superior à Oferta Pública de Ações agendada pela Telefônica para o dia 19 de novembro de 2009 ao preço de $\mathrm{R} \$ 50,50$ por ação. Somado a acordos de opções com terceiros, a Vivendi se colocou na condição de, ao exercer o direito de opção, alcançar a participação acionária de 53,7\% na GVT, anunciando Oferta Pública de Ações no valor de $\mathrm{R} \$ 56,00$ por ação para aquisição de $100 \%$ das ações da GVT. O controle da GVT pela Vivendi foi confirmado em 10 de dezembro de 2009, quando, em Assembléia Geral Extraordinária de acionistas da GVT, foi aprovada a substituição dos integrantes do conselho de administração da GVT pelos nomes indicados pelo grupo francês. Em 10 de dezembro de 2009, a Vivendi já detinha 78,7\% de participação na GVT. Em 8 de janeiro de 2010, a Vivendi comunicou que lançaria uma Oferta Pública de Aquisição (OPA) para as ações remanescentes da GVT, então correspondentes a 13,22\% do capital social da GVT para o fim de cancelar o registro de capital aberto da GVT na Bovespa. O negócio gerou no país a presença de um novo grupo estrangeiro no cenário de concorrência na telefonia e quiçá na TV por assinatura, haja vista a expectativa de que a Vivendi utilize da aquisição da GVT para trazer ao Brasil sua divisão de TV por assinatura chamada Canal Plus, hoje presente na Guiana Francesa, além do Canal Sat, segundo maior operador de DTH na Europa, inicialmente projetando-se o uso de DTH para as transmissões do Canal Plus, e, se concretizada a aprovação do Projeto de Lei 29, a transmissão via IPTV.

Foi também o ano de concretização da aquisição do controle indireto da Intelig Telecomunicações pela TIM Participações anunciada em fato relevante de 16 de abril de 2009. Esta incorporou a Holdco Participações, empresa que detinha $100 \%$ do capital da Intelig e era controlada integralmente pela JVCO Participações, que por sua vez era controlada pela Docas Investimentos, do empresário Nelson Tanure. Como remuneração, a JVCO recebeu $6,15 \%$ do total das ações ordinárias e $6,15 \%$ do total de ações preferenciais da TIM Participações à época da operação, montante de participação variável segundo certos fatores, como o montante da dívida líquida da Intelig quando a operação fosse mais tarde concluída.

Revista de Direito, Estado e Telecomunicações, v. 2, n. 1, p. 1-44 (2010)

DOI: https://doi.org/10.26512/1str.v2i1.21682 
As surpresas do setor de telecomunicações no ano de 2009 não foram todas positivas, na medida em que a sociedade brasileira presenciou inerte $\mathrm{o}$ escancarado desvio de finalidade do fundo de universalização das telecomunicações. ${ }^{14}$ Foi o ano em que ficou conhecido o destino reservado ao FUST pela Presidência da República e implementado sem alarde, ou qualquer divulgação pública, em finais de 2008. Na aprovação do relatório de contas do Governo Federal pelo Tribunal de Contas da União (TCU) referente a 2008, reconheceu-se que a disponibilidade total do FUST fora reduzida de R \$ 5,3 billhões, em 2007, para R \$ 3,2 bilhões, em 2008, sem a esperada utilização dos meros $\mathrm{R} \$ 7,3$ milhões alocados na Lei Orçamentária Anual (LOA/2008) para o programa "Universalização dos Serviços de Telecomunicações". Segundo o relatório do TCU, a redução da disponibilidade do FUST decorreu de desvinculação de recursos do fundo para pagamento da dívida pública. A se manter essa postura governamental, o destino do FUST pode ser o mesmo do Fundo da Marinha, que, no mesmo período, foi corroído em $\mathrm{R} \$ 20$ bilhões para alívio da dívida pública federal. Se o Fundo da Marinha servir como medida no montante de desvio para pagamento da dívida pública, ao FUST estará reservado um destino sombrio e à sociedade, um destino talvez ainda mais sombrio, já que despida dos benefícios para o qual fora instituído, ilicitamente tributada para além da carga tributária oficial do país, e ainda possivelmente onerada em futuro próximo se o Judiciário der ganho de causa a esperadas ações de restituição de indébito por parte da parcela de consumidores/usuários que tiverem condições de seguir o procedimento para devolução do percentual desviado de recursos.

No que concerne ao exercício do direito à liberdade de participação democrática e inspirado no modelo tradicional das conferências nacionais de saúde, o ano de 2009 ficou para a história como o ano da primeira Conferência Nacional de Comunicação (CONFECOM), convocada em

${ }^{14}$ Em estudo sobre políticas de serviço universal publicado pelo Regulatel em 2006, dos 13 países detentores de fundos de universalização na América Latina, seis deles haviam desembolsado entre $16 \%$ e $100 \%$ do montante do fundo, enquanto sete países, dentre eles, o Brasil, não haviam aplicado qualquer montante do fundo projetos de universalização (STERN, Peter A.; TOWNSEND, David. New models for universal access in Latin America. Regulatel/World Bank, agosto de 2006). 
decreto presidencial publicado em 17 de abril de 2009 para os dias $1^{\circ}$ a 3 de dezembro, mais tarde, reagendada para 14 a 17 de dezembro de 2009, sob o título "Comunicação: Direitos e Cidadania na Era Digital" com recursos inicialmente previstos de $\mathrm{R} \$ 8,5$ milhões, e ao final contingenciados para $\mathrm{R} \$$ 1,6 milhões. Em julho de 2009, a discussão sobre a temática da conferência se acirrou entre radiodifusoras e entidades não-governamentais de democratização das comunicações, em que as primeiras, com receio de que a conferência servisse de palco para manifestação das insatisfações com o sistema atual de concessões, propunham que a temática se concentrasse na internet e em questões tecnológicas futuras, afirmando que o uso da internet não afastaria a condição de radiodifusão das transmissões e que, portanto, o uso da internet como plataforma para transmissão de TV exigiria que este ambiente fosse submetido às mesmas regras aplicáveis às radiodifusoras. A frase de efeito que foi utilizada pelo vice-presidente de relações institucionais das organizações Globo e representante da Abert na Comissão Organizadora da Conferência foi: "A simples facilidade tecnológica [de transmissão via internet] derroga a Constituição? Ou o país quer ordem e progresso?". Representantes da sociedade civil, por sua vez, enfatizaram a necessidade de se incluir na temática da conferência problemas presentes de estruturação do sistema radiodifusor. $O$ representante do Coletivo Intervozes, Jonas Valente, lançou o lema de que "precisamos discutir os novos desafios à luz de velhos problemas". A tensão entre a participação empresarial e da sociedade civil aumentou a partir de julho de 2009, com as oito entidades representantes do setor empresarial se recusando a participarem de reunião da comissão organizadora do evento do dia 22 de julho de 2009, tendo seu pedido de adiamento da reunião negado ao exigirem que se fixassem "premissas e conceitos" como condição para sua participação da CONFECOM. Com isso, a aprovação do regimento interno da conferência foi adiada mais uma vez, com o consequente impacto na realização das etapas regionais. No dia 5 de agosto de 2009, os Ministros da Comunicação (Hélio Costa), da Secretaria de Comunicação Social (Franklin Martins) e da Secretaria Geral da Presidência (Luiz Dulci) envidaram esforços no sentido de convencerem os representantes empresariais a se manterem na conferência, oferecendo um "quórum qualificado" para votação com $40 \%$ para o segmento empresarial. Das associações empresariais que inicialmente compunham a comissão organizadora da Revista de Direito, Estado e Telecomunicações, v. 2, n. 1, p. 1-44 (2010) DOI: https://doi.org/10.26512/lstr.v2i1.21682 
CONFECOM (Abert, Abrafix, ABTA, ANJ, Telebrasil e ABRA), somente a Telebrasil e Associação Brasileira de Radiodifusores (ABRA), que reúne os Grupos Bandeirantes e RedeTV, nela permaneceram. Superado o debate, em 9 de setembro de 2009, a comissão organizadora finalmente definiu o temário da CONFECOM em três eixos temáticos: "Produção de Conteúdo"; "Meio de Distribuição" e "Cidadania: Direitos e Deveres", cada eixo contendo dez temas associados ou linhas de discussão, que foram em seguida divulgados pelo Ministério das Comunicações. A linha mais polêmica de "Controle Social da Mídia" foi traduzida para "Participação Social nas Comunicações". A proposta dos movimentos sociais de um quarto eixo temático intitulado "Sistemas" foi rechaçada pelos representantes das empresas, qualificando-a como "amebão": um eixo sem formas claras. Nele estariam questões como órgãos reguladores, processo de outorgas, papel dos Estados na comunicação. O tema do "Marco Regulatório", por sua vez, embora proposto por parlamentares e representantes da Secretaria de Comunicação Social (Secom), não contou com o apoio das empresas como eixo principal e foi considerado um "eixo transversal" que permearia todos os outros eixos.

Assim, a questão do marco normativo das comunicações não foi entendida pela organização do evento como uma questão de decisão política, mas como um dado que faria às vezes de bitola para as discussões de fundo do setor.

No mesmo dia 9 de setembro, também foi definido, por demanda dos representantes de movimentos sociais, que os temas não fossem determinantes, mas apenas indicativos dos debates que seriam conduzidos na CONFECOM.

O conjunto das deliberações da CONFECOM é vasto e compõe volumosos cadernos de propostas aprovadas, não aprovadas e não apreciadas editados pela comissão organizadora. Apesar da profusão de pontos levantados na conferência, algumas das deliberações transpareceram o tom do encontro, tais como: a aprovação de apoio à criação, por lei, de uma política que garanta a veiculação de conteúdos nacionais e regionais, com produção independente, nos meios de comunicação eletrônicos, assegurada a liberdade de escolha desta produção pelos meios eletrônicos e observados os princípios de respeito aos direitos humanos, universalidade e acessibilidade ao direito à comunicação, igualdade, equidade, respeito à 
diversidade, aos direitos autorais da mulher, promoção da justiça social, laicidade do Estado e transparência dos atos públicos; a aprovação da criação de conselhos de comunicação nos âmbitos federal, estaduais e municipais para acompanhamento da execução de políticas públicas no tocante à regulação de conteúdo, políticas de concessões, mecanismos de distribuição, dentre outros, bem como para garantia do exercício do direito à comunicação, além da reativação imediata do Conselho de Comunicação Social paralisado desde 2006 por omissão da Mesa Diretora do Senado Federal; a aprovação da criação de política pública voltada à integração latino-americana, mediante transmissão de conteúdos de caráter educativo, cultural, informativo e ambiental dos países da região; a aprovação da criação de um sistema público de distribuição física de conteúdos produzidos pelas redes de comunicação e cultura, bem como a submissão da distribuição de produção cultural financiada com dinheiro público às licenças de creative commons; aprovação de limites à concentração de conteúdo para além de $25 \%$ da grade de programação em plataformas fechadas de distribuição (MMDS, DTH, TV a Cabo, celular, dentre outras); a aprovação de conjunto de propostas voltadas a tornar mais efetiva a fiscalização e punição de emissoras de rádio e TV que não cumpram as regras pertinentes; a aprovação da proposta geral de descriminalização das rádios comunitárias; a aprovação de criação de um código de ética do jornalismo brasileiro para garantia da qualidade da informação veiculada pelos meios de comunicação; a aprovação da proposta de que o conteúdo oferecido por serviço de radiodifusão digital seja livre de medidas de proteção tecnológica que impeçam ou restrinjam o seu acesso e uso legítimo; a aprovação da criação do serviço de banda larga em regime público, com metas de universalização do acesso, qualidade, controle tarifário e garantia de continuidade; a declaração do acesso à internet como direito fundamental a ser garantido pelo Estado; a aprovação de proposta de edição de um plano de outorgas para a TV por assinatura para expansão a todos os municípios brasileiros e de uma política de massificação da TV por assinatura, mediante unificação da regulamentação da televisão por assinatura em um serviço único, em uma rede única e pública; a vedação da sublocação de espaços na grade de programação de radiodifusores, bem como o estabelecimento de quesitos relativos à diversidade na oferta, a complementaridade entre os sistemas público, privado e estatal, dentre Revista de Direito, Estado e Telecomunicações, v. 2, n. 1, p. 1-44 (2010)

DOI: https://doi.org/10.26512/1str.v2i1.21682 
outros, nos processos de outorga; a revisão da legislação vigente para o fortalecimento dos meios de comunicação não-comerciais; a proposta de criação de conselhos de gestão dos fundos de fomento à radiodifusão pública nos âmbitos federal, estadual e municipal para definição da política de uso dos recursos e de acompanhamento dos gastos; a utilização do FUST para financiamento da infraestrutura básica de acesso à telefonia fixa e móvel em localidades não atendidas; a democratização do acesso à internet mediante criação e ampliação de telecentros e acesso qualificado à rede em todas as escolas da rede pública de ensino, em bibliotecas e em espaços públicos comunitários; a vedação a ocupantes de cargos políticos que exerçam a função de comunicadores em qualquer concessão pública de comunicação durante o exercício do mandato e desde 6 meses antes das eleições; a promoção da descentralização da produção de conteúdo dos estados para além do eixo Rio/São Paulo; o estímulo à veiculação televisiva de produções sobre ciência e tecnologia no Brasil e sua história; o dever de criação pelo governo federal de cinemas e cineclubes populares comunitários para formação de plateia; a ampliação da discussão sobre direitos autorais; a proposta de pesquisa para identificação das rádios comunitárias no país para ampla divulgação; o dever de assegurar a neutralidade da internet por meio de tratamento isonômico a todos os interessados, bem como manter livre de restrições a circulação de informações pela internet. Ainda a proposta de aprovação de lei que defina os direitos civis nas redes digitais, que inclua: direito ao acesso à internet sem discriminação de qualquer espécie; direito à acessibilidade plena; direito à abertura de redes e ao compartilhamento do sinal de internet; direito à comunicação não-vigiada. Ainda, o direito à privacidade na internet, com regulação eficaz do habeas data; a utilização de recursos do FUST para investimento na ampliação do alcance da rede RNP e de outras redes alternativas de acesso à internet; o apoio ao uso da rede elétrica para provimento de acesso à internet no Brasil; o apoio a políticas de incentivo, investimento e valorização da tecnologia nacional; a proposta de constituição de uma empresa nacional de desenvolvimento e produção de equipamentos de telecomunicações de grande porte e competitiva; a priorização, na comunicação social, da educação em direitos humanos com ênfase nos aspectos da tolerância, da diversidade e da educação em direitos; a ampliação dos recursos de acessibilidade nas mídias e na publicidade 
oficial para proteção do direito à informação, mediante incremento da audiodescrição e do uso da Língua Brasileira de Sinais (LIBRAS); a manutenção do programa Voz do Brasil e seu aperfeiçoamento constante; a criação de um conselho federal de jornalismo; a proposta de extensão a todas as emissoras e empresas de rádio e televisão educativas, vinculadas à Administração Pública, dos princípios, direitos, deveres, objetivos, modelos de gestão e de financiamento, dispostos na Lei 11.652/08, que autorizou a criação da Empresa Brasil de Comunicação (EBC); a defesa da necessidade de uma nova e democrática legislação para a imprensa em um texto orgânico, não segmentado, mediante agilização do direito de resposta ou de retificação, a garantia de pluralidade de versões em matéria controversa, dentre outras propostas aprovadas. No campo das propostas não aprovadas, as mais significativas foram: a não-aprovação da proposta de imposição de $30 \%$ de conteúdos regionais e de produções independentes e de $10 \%$ de horas veiculadas semanalmente para transmissão de conteúdos educativos, culturais, informativos e artísticos para prestadores de serviço de comunicações que transmitem conteúdos audiovisuais, incluindo o rádio e a TV abertos e a TV por assinatura; a não-aprovação da proposta de enquadramento no SIMPLES pela capacidade econômica, ao invés do uso do critério da natureza do serviço; a não-aprovação da proposta de criação de uma agência nacional de regulação da mídia sobre qualidade da programação midiática, concessões de canais e redes de TV e rádio, limites de concessão por tipo de veículo e por grupos midiáticos privados ou estrangeiros; a não-aprovação da proposta de instituição de cotas crescentes de veiculação nas emissoras de televisão de sinal aberto e fechado de animação produzida nacionalmente; a não-aprovação da proposta de promoção da separação estrutural de redes, determinando o desmembramento das empresas de telecomunicações em empresas detentoras de redes e outras prestadoras de serviços; a não-aprovação da proposta de fortalecimento da TELEBRÁS com recursos do FUST para fornecimento de serviços de telecomunicações e coordenação da criação de infraestrutura pública a partir de redes ociosas das empresas estatais; a nãoaprovação de proposta de um plano nacional de banda larga com adesão do setor privado apoiado na desoneração tributária dos serviços e investimentos, com adequação de regras e custos de direitos de passagem, de competência normativa estadual e municipal, de alocação de faixas de Revista de Direito, Estado e Telecomunicações, v. 2, n. 1, p. 1-44 (2010) DOI: https://doi.org/10.26512/1str.v2i1.21682 
radiofrequências para a construção de redes de acesso em banda larga, a eliminação de restrições à obtenção de novas outorgas de serviços por detentores de outras outorgas ou da origem do capital da empresa; a nãoaprovação de proposta de modelo de outorga para uso de espectro pela TV e rádio digital proporcional ao espaço necessário à utilização do serviço, vedada a multiprogramação pelos concessionários; a não-aprovação de proposta de garantia de redistribuição das concessões de rádio e TV para garantia da proporcionalidade de $1 / 3$ dos canais para o setor público, 1/3 para o setor privado e $1 / 3$ para o setor estatal; a não-aprovação de proposta de incidência de tributos "por fora", de vedação de incidência de tributo sobre tributo e de atribuição à ANATEL da competência para definição dos elementos que compõem a receita de serviço de telecomunicações regulado pela União; a não-aprovação da proposta de redução das taxas da TFI e TFF com projeção de redução de preços ao usuário final.

\section{Julgados do setor de telecomunicações em 2009}

A esfera judicial seguiu sua tradição de esgotamento das questões jurídicas pelo embate de argumentos construídos nas instâncias processuais próprias, e, portanto, sua análise transporta o setor para um espaço e tempo de certa forma destacado, em grande parte, das angústias setoriais executivas e legislativas vivenciadas em 2009. O detalhamento de tais decisões encontra-se na última seção deste número da Revista de Direito, Estado e Telecomunicações, mas cabe aqui destacar sinteticamente as principais questões jurídicas que sofreram pronunciamento das instâncias superiores no Judiciário brasileiro.

O Supremo Tribunal Federal firmou o entendimento de que a totalidade da Lei de Imprensa (Lei 5.250/67) não fora recepcionada pela Constituição Federal de 1988, mantida, todavia, a possibilidade de conformação legislativa da liberdade de imprensa no que se refere ao direito de resposta, devido ao entendimento de que o art. $5^{\circ}, \mathrm{V}$, da Constituição Federal, configura-se em norma de eficácia plena, bem como de outras possibilidades de conformação legislativa da liberdade de imprensa, tais como a proteção do sigilo da fonte, a responsabilidade penal por calúnia, injúria ou difamação, as limitações pertinentes a diversões e espetáculos públicos e a proteção da família de programação de rádio e televisão nas situações 
especificadas pela Constituição. O STF ainda aprovou, em 2009, a Súmula Vinculante $\mathrm{n}^{\mathrm{o}} 27$, com o enunciado de que compete à Justiça Estadual julgar causas entre consumidor e concessionária de serviço público de telefonia quando a ANATEL não seja litisconsorte passiva necessária, assistente nem oponente.

O Supremo Tribunal Justiça, por sua vez: a) aprovou a súmula 371, de interesse para a solução de litígios pertinentes à desestatização do Sistema Telebrás, disciplinando que, para apuração do Valor Patrimonial da Ação (VPA) nos contratos de participação financeira para aquisição de linha telefônica, é levado em conta o balancete do mês da integralização do pagamento; b) decidiu que a comercialização de terminais portáteis capazes de mobilidade que ultrapasse os limites efetivos da propriedade do cliente para acesso de serviço telefônico fixo não viola a regulamentação da ANATEL e, igualmente, não implica em concorrência desleal com as prestadoras de Serviço Móvel Pessoal (SMP); c) decidiu pelo ressarcimento de valores cobrados por chamadas sem a respectiva discriminação em fatura; d) se pronunciou no sentido de autolimitação da função jurisdicional frente à inação administrativa da Administração Pública sobre pedido de funcionamento de rádio comunitária, determinando que a intervenção do Judiciário se limita a fixar prazo para que a Administração delibere sobre processo administrativo; e) declarou a impossibilidade jurídica de cobrança de taxas ou preços públicos pelo direito de uso de bem público (vias públicas) para instalação de equipamentos destinados à prestação de serviços à coletividade por concessionária de STFC, por não se caracterizar como atividade empresarial ou industrial; f) declarou, por outro lado, que esse entendimento de isenção das concessionárias de STFC do pagamento pelo uso de vias públicas não se estende à prestação de serviço de TV a Cabo, que, nos termos dos arts. 73 e 74 da Lei Geral de Telecomunicações, pode sofrer a cobrança de preços justos e razoáveis pela utilização de bens públicos; g) entendeu pela legalidade da incidência da Contribuição de Intervenção no Domínio Econômico instituída pelo art. $1^{\circ}$, da Lei 10.168/2000 (CIDE-Tecnologia) sobre os royalties correspondentes à receita da exploração de serviços de telecomunicações, entendendo inexistir bis in idem tributário entre a CIDE-Tecnologia e as contribuições para o FUST e para o FUNTTEL; h) decidiu pela plena aplicabilidade das disposições de classificação indicativa contidas no art. 19, da Portaria MJ no Revista de Direito, Estado e Telecomunicações, v. 2, n. 1, p. 1-44 (2010) DOI: https://doi.org/10.26512/lstr.v2i1.21682 
1.220/2007, mesmo na vigência do horário de verão; i) entendeu pela inexistência de invasão da competência da ANATEL por parte de Procon municipal que aplica multa à concessionária de telefonia fixa por descumprimento de prazo por ele fixado para instalação de linha telefônica, definindo como legítimo o exercício de poder de polícia mediante aplicação de sanções administrativas quando as condutas praticadas no mercado de consumo atingirem diretamente o interesse de consumidores; $\mathrm{j}$ ) reforçou o entendimento de que a suspensão de serviço telefônico por inadimplência de usuário é legítima e não gera direito para o consumidor à indenização por dano moral; k) decidiu pela ilegalidade do repasse do PIS e da COFINS na fatura telefônica dos consumidores, caracterizando-se, tal prática, como abusiva, sujeitando as concessionárias à devolução em dobro do que indevidamente cobrado.

No âmbito da jurisprudência trabalhista, firmou-se o entendimento, no Tribunal Superior do Trabalho, de que não configura violação à súmula 331 do TST a terceirização de atividades inerentes, acessórias ou complementares aos serviços de telecomunicações, nos termos do art. 94, da LGT, não se confundindo, tais atividades, com os serviços de telecomunicações em seu sentido estrito, assim definidos no art. $60, \S 1^{\circ}$ da LGT.

$\mathrm{Na}$ esfera administrativa, o Tribunal de Contas da União manifestou-se em diversas ocasiões em temas pertinentes ao setor de telecomunicações. $\mathrm{O}$ TCU, em 2009, se posicionou pela: a) irregularidade do procedimento adotado pela ANATEL para expedição de autorização à Unicel do Brasil Telecomunicações Ltda. para exploração do serviço móvel especializado (SME) na subfaixa de 411,675 a 415,850 MHz e 421,675 a 425,850 MHz, reconhecendo entretanto a inexistência de dano ao interesse público ou a direitos de terceiros e a regularização da situação em virtude da edição da

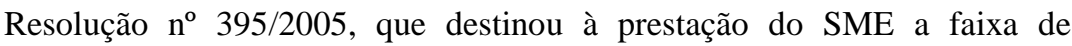
411,675 a 415,850 MHz e 421,675 a 425,850 MHz; b) confirmação de determinação de que a ANATEL não mais promova o cancelamento automático de débitos decorrentes de taxa de fiscalização não pagos no prazo ou após notificação, acolhendo, porém, as razões da agência de pertinência do cancelamento de débitos não atingidos por prescrição ou decadência, quando o custo de efetuar as cobranças dos valores não pagos for superior ao valor passível de ser arrecadado; c) inaplicabilidade do limite 
de 5\% para despesas administrativas e operacionais em projetos financiados pelo FUNTTEL, quando se tratar de alocação direta de recursos à Fundação $\mathrm{CPqD}$, tendo em vista a expressa previsão legal para fixação de repasses necessários à preservação da capacidade de pesquisa e desenvolvimento tecnológico do $\mathrm{CPqD}$, nos termos do art. 190 da Lei Geral de Telecomunicações; d) conformidade dos procedimentos adotados pela ANATEL na adaptação dos contratos de concessão do Serviço Móvel Celular (SMC) em autorizações do Serviço Móvel Pessoal (SMP), bem como confirmação de não aplicabilidade ao SMP do instituto da reversibilidade de bens, por um lado, embora tenha exigido que a ANATEL firme termo aditivo aos termos de autorização do SMP para fazer constar que os controles tarifários contidos nos instrumentos de concessão ou autorização do SMC foram incorporados aos novos termos de autorização; e) aprovação do parecer prévio sobre as contas do Governo Federal referentes ao exercício de 2008, revelando, durante a apreciação de receitas, despesas e disponibilidade dos Fundos do Poder Executivo Federal, a redução de disponibilidade financeira do Fundo de Universalização dos Serviços de Telecomunicações (FUST), que experimentou uma queda de R \$ 5,3 bilhões em 2007, para $\mathrm{R} \$ 3,2$ bilhões em 2008, em virtude de utilização dos recursos para pagamento da dívida pública.

\section{Projeções para o setor de telecomunicações}

A esperada aprovação do Projeto de Lei 29/2007 não ocorreu em 2009, mas o Congresso Nacional definitivamente avançou nas discussões sobre uma lei que unificasse o tratamento normativo dos serviços de mídia por meios confinados. A iniciativa de projeto de lei concorrente no Senado Federal impulsionou a tramitação do PL 29, na Câmara dos Deputados. No Senado Federal, em 11 de maio de 2009, foi apresentado o PLS 182/2009 à Comissão de Ciência, Tecnologia, Inovação, Comunicação e Informática (CCT), como parte das conclusões da Subcomissão Temporária da Regulamentação dos Marcos Regulatórios, que atuou de abril de 2007 a abril de 2009, na Comissão de Assuntos Econômicos. O PLS 182 era parte do relatório da subcomissão desde 2007 e não sofreu alteração no relatório final. Dentre as alterações propostas pelo PLS 182 estão a revogação da Lei do Cabo e a criação de um serviço único intitulado "Serviço de Televisão por Assinatura”, nele incluídos o MMDS, o DTH, a TV a Cabo, ou qualquer

Revista de Direito, Estado e Telecomunicações, v. 2, n. 1, p. 1-44 (2010)

DOI: https://doi.org/10.26512/lstr.v2i1.21682 
outro serviço congênere a ser criado por regulamentação, vinculado à Lei Geral de Telecomunicações (LGT), sem cotas de qualquer natureza ou limitações a capital estrangeiro, bem como sem limites para que empresas de telecomunicações prestem o novo serviço, ou mesmo prazos para adaptação. São mantidos, todavia, os canais do Legislativo, um canal Judiciário, um canal universitário, um educativo e um comunitário. É mantida a obrigatoriedade de transmissão dos sinais da TV aberta conhecido como must carry, autorizando-se a ANATEL a liberar parcelas das obrigações de must carry por razões de impossibilidade técnica. Finalmente, uma previsão normativa da Lei do Cabo (art. $4^{\circ}, \S 2^{\circ} \mathrm{c} / \mathrm{c}$ art. 44 , caput, da Lei 8.977/95) até então ineficaz, embora tenha sido utilizada em 2008 e 2009 como argumento contra regulação pela ANATEL da cobrança de ponto extra, foi mantida no PLS 182, exigindo-se consulta pública para qualquer ato normativo referente ao novo serviço de televisão por assinatura, ouvido o agonizante Conselho de Comunicação Social. O PLS 182 foi introduzido no bojo de oito projetos de lei para o setor de infraestrutura e contém, em sua exposição de motivos, a opção por se evitar um modelo de regulação de serviços de telecomunicações assentado no tipo de rede utilizada, apontando para a tendência de regulação por serviços ou de regulação convergente. Em 2 de dezembro de 2009, o substitutivo do deputado Paulo Henrique Lustosa (PMDB/CE) ao PL 29/2007 foi aprovado na Comissão de Ciência e Tecnologia, Comunicação e Informática, da Câmara dos Deputados. Inauguradas em 2010 as discussões do PL 29 na Comissão de Constituição e Justiça da Câmara dos Deputados, é aguardada para este ano a sua aprovação nesta Casa do Congresso. A dúvida que permeia qualquer projeto de lei em ano eleitoral, entretanto, é se haverá tempo para sua aprovação no Senado Federal.

Em outra frente, mais um passo foi dado rumo à promoção de maior competição no setor e espera-se para 2010 a aprovação do Regulamento sobre Exploração de Serviço Móvel Pessoal (SMP) por meio de Rede Virtual.

Tolhido de R \$ 2,1 bilhões, o ano de 2010 será decisivo para se saber se o FUST permanecerá como um artifício para alívio de contas do Governo Federal, ou se finalmente se levará a sério sua destinação legal para a universalização dos serviços de telecomunicações. 
A TV digital não aspira, em 2010, a uma posição de destaque, mas se a tendência de encolhimento do espectro vivenciado em 2009 se agravar, a faixa de $700 \mathrm{MHz}$ certamente suscitará maiores embates entre os prestadores de Serviço Móvel Pessoal (SMP) e os radiodifusores.

Espelhado na provocação que partiu da $\mathrm{Oi}$, no primeiro semestre de 2009, ao propor a redução da VC-1 e o consequente impacto no valor de remuneração de uso de rede do SMP (VU-M), o ano de 2010 também deve presenciar a intensificação dos debates sobre as tarifas de interconexão e a pertinência de subsídios cruzados na relação STFC-SMP.

Finalmente, o tema ao mesmo tempo antigo e atual de questionamento das relações entre os serviços tradicionais de telecomunicações e o meio universal de comunicação da internet promete manter-se suficientemente distante de questões pontuais que lhe dizem respeito, tais como: a proteção de mídias tradicionais na internet externado na adesão da Abert e de diversos representantes de mídias tradicionais à chamada declaração de Hamburgo sobre direitos de propriedade intelectual, firmada em 25 de junho de 2009 por iniciativa do Conselho Europeu de Editores (European Publishers Council) e da Associação Mundial de Jornais (World Association of Newspapers) em defesa dos direitos de propriedade intelectual na internet; e a dificuldade de manutenção das fronteiras entre o Serviço de Comunicação Multimídia (SCM) e o Serviço Telefônico Fixo Comutado (STFC), como demonstrou o caso Atrium. Nele, a empresa A. Telecom, antiga Atrium, voltada a prestação de serviços corporativos, foi acusada de prestar clandestinamente STFC via licença de SCM, atingindo, por via transversa, os direitos dos usuários de STFC em aspectos como o de escolha do código de operadora para ligações de longa distância, de portabilidade, de vedação de tratamento privilegiado no compartilhamento de infraestrutura, de vedação de autorização a empresa controlada por concessionária para prestação de STFC na sua mesma área de concessão e no uso irregular de Plano de Numeração do STFC. Afora a exigência do órgão regulador de que as relações comerciais entre a concessionária de STFC e a autorizada de SCM fossem deixadas transparentes para o consumidor/usuário de SCM e STFC, em especial, na operação das Centrais Privativas de Comutação Telefônica (CPCTs) do STFC, o episódio foi seguido da retomada pela Telefônica de atividades caracterizadas como típicas do STFC antes desempenhadas pela prestadora de SCM (A. Revista de Direito, Estado e Telecomunicações, v. 2, n. 1, p. 1-44 (2010) DOI: https://doi.org/10.26512/1str.v2i1.21682 
Telecom). O devido posicionamento da internet no contexto jurídico do setor de telecomunicações deve permanecer, assim, evidente no horizonte, todavia inalcançável em sua plena dimensão. Não há indicações de que os diversos aspectos da internet em sua relação com o setor de telecomunicações sejam em breve codificados em regulamentação abrangente das relações entre as novas (tele)comunicações e os tradicionais serviços, utilidades e infraestrutura do setor.

O Conselho Editorial 
